\title{
Three challenges to contemporaneous taxonomy from a licheno-mycological perspective
}

\author{
ROBERT LÜCKING \\ Botanischer Garten und Botanisches Museum, Freie Universität Berlin, Königin-Luise-Straße 6-8, 14195 Berlin, Germany \\ झ" r.luecking@bgbm.org; ○ https://orcid.org/0000-0002-3431-4636
}

\begin{abstract}
This paper discusses three issues that challenge contemporaneous taxonomy, with examples from the fields of mycology and lichenology, formulated as three questions: (1) What is the importance of taxonomy in contemporaneous and future science and society? (2) An increasing methodological gap in alpha taxonomy: challenge or opportunity? (3) The Nagoya Protocol: improvement or impediment to the science of taxonomy? The importance of taxonomy in society is illustrated using the example of popular field guides and digital media, a billion-dollar business, arguing that the desire to name species is an intrinsic feature of the cognitive component of nature connectedness of humans. While continuous societal support of a critical mass of taxonomists is necessary to catalogue all species on Earth, it is shown that this is a finite task, and a proposal is made how a remaining 10 million species can be catalogued within 40 years by 1,000 well-trained and dedicated taxonomists, with an investment of $\$ 4$ billion, corresponding to $0.0001 \%$ of the annual global GDP or $0.005 \%$ of annual military expenditures. Notorious undercitation of actually used taxonomic resources and lack of coverage of impact metrics for monographs and other taxonomic work that cannot be published in indexed journals is discussed and suggestions are made how this problem can be remedied. An increasing methodological gap in approaches to taxonomy, between classic morphological and advanced genomic studies, affects in particular taxonomists in biodiversity-rich countries and amateurs, also regarding proper training to apply advanced methods and concepts. To counterbalance this problem, international collaborations bringing different expertise to the table and undertaking mutual capacitation are one successful remedy. Classic taxonomy still works for many groups and is a first approach to catalogue species and establish taxon hypotheses, but ultimately each taxonomic group needs to be studied with the array of methods proper to the group, including descriptive work. Finally, the Convention on Biological Diversity (CBD) and the Nagoya Protocol has put additional burden on basic biodiversity science. Using lichenology in Latin America and Brazil as an example, it is shown that the spirit of non-monetary benefit-sharing proper to taxonomy and systematics, namely capacitation, joint publications, and shared reference collections, has been increasingly implemented long before the $\mathrm{CBD}$ and the
\end{abstract}

Nagoya Protocol, and does not need additional "policing". Indeed, the Nagoya Protocol puts the heaviest burden on taxonomy and researchers cataloguing biodiversity, whereas for the intended target group, namely those seeking revenue gain from nature, the protocol may not actually work effectively. The notion of currently freely accessible digital sequence information (DSI) to become subject to the protocol, even after previous publication, is misguided and conflicts with the guidelines for ethical scientific conduct. Through its implementation of the Nagoya Protocol, Colombia has set a welcome precedence how to exempt taxonomic and systematic research from "access to genetic resources", and hopefully other biodiversity-rich countries will follow this example.

Key words: amateur taxonomy, biopiracy, fungal diversity, impact factor, sixth mass extinction, taxonomic impediment

\section{Introduction}

Taxonomy is the most fundamental discipline in biodiversity research. It is the science that puts names on organisms and groups of related organisms (taxa) and arranges these in hierarchical classification systems, with the focus in establishing names (Judd et al. 2007; Guerra-García et al. 2008; Kirk et al. 2008; Wilkins 2011; Lew 2018). In contrast, systematics is concerned with the relationships between taxa and not primarily with naming them, although both areas are strongly interdependent. Taxonomy establishes hypotheses about relationships between individuals or lower-level taxa and gives these hypotheses formal names, whereas systematics tests these relationships, on the base of which the taxonomy is then adjusted.

Taxonomy is divided into three approaches: (1) alpha taxonomy, the naming of species ("microtaxonomy"); (2) beta taxonomy, the arrangement of species into higher-level classifications through named higher taxa ("macrotaxonomy"); and (3) gamma taxonomy, the naming and classification of infraspecific entities (Mayr 1968, 1982a; Winston 1999; Disney 2000; Tahseen 2014). This division seems at first counterintuitive, as it contradicts the 
logical sequence from individuals to species to higher taxa, i.e. gamma (= below species), alpha (= species), beta (= above species). However, the term alpha ('leader') taxonomy for naming species properly reflects the fact that species are the fundamental unit of biodiversity research: higher classifications and the Tree of Life are ultimately based on species, and infraspecific entities cannot be established before species have been named first. This is also embedded in the various rules of nomenclature, for lichenology and mycology the International Code of Nomenclature for algae, fungi, and plants (ICN; Turland et al. 2018).

The ICN, as well as the rules of nomenclature for animals and bacteria, employ binomials for species names. This Linnean-based way of naming is often considered outdated (Cantino et al. 1999; Ereshefsky 2002, 2007), but remains a masterpiece of combinatorics, as it allows to maximize the number of species names that can be memorized by the human brain (Lücking 2019). The Linnean binomial allows to immediately place species into the Tree of Life through their genus component, a feature not possible with alternative, non-Linnean names (Cantino et al. 1999; Lücking 2019). The binomial thus combines elements of alpha and beta taxonomy, since the genus name incorporates the lowest hierarchical level at which species are being classified, and at the same time provides the linkage to higher categories. The subdiscipline of strict alpha taxonomy does therefore not exist, as naming species simultaneously means to classify them into genera as the next higher category. Therefore, alpha taxonomists are also beta taxonomists by default, and one could use the term "lower beta" taxonomy to reflect this fact. This paper focuses on alpha and "lower beta" taxonomy which, compared to "higher beta" and gamma taxonomy, are the subdisciplines of taxonomy which have faced, and continue to be facing, the most substantial challenges in contemporaneous biodiversity research (Kitching 1993; Carvalho et al. 2007; Wheeler 2008; Ebach et al. 2011; Pearson et al. 2011; Vinarski 2019).

One may consider this contribution redundant, as almost everything that could be said about this topic in the field of mycology and beyond has been eloquently expressed by Korf (2005) and on a more general level by Kim \& Byrne (2006), Wheeler (2004, 2008, 2010, 2018), and many others. However, new challenges have emerged particularly with molecular advances and the recent implementation of the Nagoya Protocol (Young 2013), both elaborated in two of the three chapters below, and new lines of thought are emerging. Also, seemingly positive developments in the recent past, such as the PEET (Partnerships to Enhance Expertise in Taxonomy) program (Rodman \& Cody 2003) and the Planetary Biodiversity Inventories program (Page 2008), by the U.S. National Science Foundation, have not survived the course of time.

\section{What is the importance of taxonomy in contemporaneous and future science and society?}

The desire and need to name species. The discipline of taxonomy is as old as humankind. While hunting and gathering as principle means of survival, humans both implicitly and explicitly employed - and still employtaxonomy ("ethnotaxonomy") when naming and classifying natural resources according to their potential uses (Sharma 1993; Godfray 2002; Manktelow 2010; Franco et al. 2015; Si 2016; Krishnamurthy \& Adams 2016). The scientific approach to taxonomy, which separates human curiosity from immediate applied aspects, goes back several thousand years, but only in the 16th century began its ascent to modern biodiversity science, with the formal birth of Linnean taxonomy in the 18th century (Linnaeus 1753, 1758; Gilmour 1951; Mayr 1982b; Stevens 2001; Minelli 2012; Wilson 2005; Tahseen 2014).

While taxonomy is a branch of science, it also continues to be the most important aspect of "citizen science", particularly expressed so in the widespread and popular use of field guides (Law \& Lynch 1988; Stevenson et al. 2003). The International Field Guides Database (International Field Guides 2020) features over 6,500 entries covering all groups of organisms around the globe, between 1954 and present, although the first modern field guides go back to the 19th century (Merriam 1890; Barrow 1998) and the database covers only a part of all such guides ever published. Some popular field guides, such as A Field Guide to the Birds of Britain and Europe in the Peterson Field Guides Series, have sold over a million times (Johnsgard 2006), and the National Audubon Society Field Guide to North American Mushrooms approximately 200,000 copies. With perhaps close to 20,000 copies sold globally, Lichens of North America (Brodo et al. 2001) is likely the most popular book on lichens published to date; while not quite a field guide, it is essentially a taxonomy book based on the expertise by one of the foremost lichenologists on North America and two outstanding nature photographers. Field guides and related books are a billon-dollar business and provide an invaluable link between amateurs and professionals (Stevenson et al. 2003; Pearson \& Shetterly 2006; Pearson et al. 2011), maintaining amateur taxonomy a favorite hobby among naturalists world-wide. Digital and social media, including websites such as iNaturalist [https://www.inaturalist.org] or Mushroom Observer [https://mushroomobserver.org], or popular Facebook groups such as Lichens Connecting People, have brought professional taxonomists, beginners and amateurs even closer together (Jatnika et al. 2019). Popular smart phone applications such as $\mathrm{Pl} @$ ntNet use the input from naturalists to gather biodiversity data (Goëau et al. 2013; Joly et al. 2016). Indeed, the desire to name species is 
an intrinsic feature of the cognitive component of human nature connectedness (Schultz 2002; Nisbet et al. 2009; Ellis et al. 2010; Cox \& Gaston 2015; Richardson et al. 2017). The science of taxonomy provides its basis.

From Linnaeus to well into the late 20th century, taxonomy thrived as an independent branch of the biological sciences, not usually concerned with practical applications and revenue-oriented thinking. Basic science is curiosity-driven, whereas applied science focuses on problem-solving. Both are not separate but inform each other, and applied science may not possible without the fundamentals of basic research, although this is not always the case (Kealey 1996; Mawatari 2004; Spector et al. 2018). Taxonomy provides the framework to name, classify, and understand our natural environment, and any applied science concerned with organisms and their derivates starts with accurately naming and identifying them (Kim \& Byrne 2006; Patterson et al. 2010; Granjou et al. 2014). Sadly, in the past few decades there has been a shift from a balance between basic and applied research to a strong focus on revenue-generating science, with governments rarely allocating up to $30 \%$ of their research budgets, but often much less, to basic science (Nelson 1959; Caulfield et al. 2012; UNESCO 2015). This has particularly affected taxonomy, with permanent positions being eliminated or replaced by other disciplines focusing more on laboratory research (Drew 2011; Hutchings 2013). The classic, paid position of a full-time taxonomist practically does not exist anymore, and institutions that still maintain such slots are likely waiting for their personnel to retire. Modern professional, university-based taxonomists are mostly professors that perform taxonomy in their spare time. Even the limited curatorial positions are normally burdened with supervisory, technical and administrative work to an extent preventing them from performing taxonomy on a regular basis. Another problem is that taxonomists who have the privilege of being paid to do taxonomy may not live up to their responsibilities (Evenhuis 2007), taking away unique opportunities from highly talented and potentially prolific early-career taxonomists that cannot find a job. This certainly does not help the cause.

The value of nature and taxonomy. While the taxonomic impediment has in part been affiliated with the ill-defined notion of taxonomy being an outdated science (Gevin 2002; Wägele et al. 2011), in reality this is a problem of society, which along with an ever growing human population has evolved a misguided focus on monetary values. With increasing pressure on what is left of our natural resources, we have arrived at a point where the importance of nature is essentually reduced to its potential use to humans (Wilson 1976; Westman 1977; Daily et al. 2000; Turner et al. 2003; Alho 2008; Ehrlich \& Pringle 2008; Duraiappah
\& Rogers 2011; Turner et al. 2012; Barber et al. 2014; Díaz et al. 2018). Politicians and business leaders have argued that the costs of protecting the environment are too high for society, threatening economic development and human expansion (Meyer 1997; Barber et al. 2014). This is an arrogant, cynical, human-centric worldview which assumes that nature only exists to serve humanity and has to recede in favor of population growth, except for what is essential to human survival. If we continue to promote this viewpoint, our planet is for sure doomed. The state of taxonomy is essentially a "bio-indicator" of the human condition, and a fundamental paradigm shift in society's consideration of nature is required to remedy this (Schultz 2002; Wilson 2002; Miller 2005; Heyd 2016; Soga et al. 2016). Nature does not exist to be explored, but has an intrinsic right of existence on its own.

Reckless exploitation of nature has often been attributed to the historical biblical concept of the "dominium terrae" (White 1967). This fundamentalistic viewpoint has been gradually replaced by a modern interpretation in the past few decades, which sees the "dominium terrae" as a responsibility to care for nature (Krolzik 1980; Kay 1989; Chryssavgis 2015; Mair 2012; Horrell 2015). In reality, in modern society there is little correlation between the destruction of nature and the dominant forms of religious beliefs, and we cannot use religion as an excuse, explanation, or solution. This is an overarching, cultural and spiritual issue of humankind. Homo sapiens, the "wise(?) man", the type of which coincidentally is Linnaeus (Notton \& Stringer 2010), is a guest on Earth, one out several million species. Guests do not destroy other people's homes but leave them in the same condition as encountered, for future patrons. The US-American environmental lawyer and advocate James Gustave ("Gus") Speth is widely quoted with the statement: "I used to think that the top environmental problems were biodiversity loss, ecosystem collapse and climate change. I thought that thirty years of good science could address these problems. I was wrong. The top environmental problems are selfishness, greed and apathy, and to deal with these we need a cultural and spiritual transformation."

This is such a profound problem that taxonomist cannot hope for it to be remedied anytime soon, if ever. Rather, taxonomists are to be concerned with the dramatic effects of the destruction of nature at an accelerating rate, leading to the sixth (or seventh) mass extinction (Wake \& Vredenburg 2008; Barnosky et al. 2011; Ceballos et al. 2015, 2017; Ceballos \& Ehrlich 2018; Shrimpton 2019; Rampino \& Shen 2019). This faces a dwindling body of experts with the challenge to catalog our planet's biodiversity at an ever accelerating rate, a paradoxical situation (Dubois 2003) that is particularly dramatic in taxa such as arthropods and fungi, with millions of species 
awaiting discovery and formal description (Hawksworth \& Lücking 2018; Stork 2018; see below).

The pressure to generate revenue has also forced taxonomy to shift into a fallacious direction of "applied taxonomy" (Subramanian 1982; Lyal et al. 2008). Particularly in biodiversity-rich countries, students in the field of biodiversity research are focusing on laboratorybased research such as natural product screening, without notion for the fundamentals of taxonomy. Countless studies analyse the potential effects of natural product extracts from lichens and other fungi, usually without any follow-up in more rigorous, clinical research, and not rarely lacking the taxonomic expertise to correctly identify what is being studied. To pick just one random example: Pratibha \& Mahesh (2016) analysed the biological activities of the "medicinally important" lichen "Parmelia perlata". No voucher material or repository thereof was cited, the taxonomic expertise consulted was referred to vaguely as an unidentified person in charge of the herbarium at University of Rajasthan, and the genus name Parmelia for this species, correctly known as Parmotrema perlatum (Huds.) M. Choisy (Hawksworth 2004), suggesting a relationship with a taxon with an evolutionary history and ecogeography entirely different from that of Parmotrema (Thell et al. 2012; Molina et al. 2017). This is particularly noteworthy as India has a plethora of highly qualified taxonomists, organized in the Indian Lichenological Society [https://www. indianlichenology.com], who could have been easily consulted or invited for collaboration. Unfortunately, there are many similar examples, and superficial and somewhat misleading reviews such as Alves \& Pontes (2017) do not help to substantiate the quality and actual practical output of such approaches.

An initially successful endeavour was the agreement between the Merck company and the Costa Rican Instituto Nacional de Biodiversidad (INBio) in 1991, supporting a large-scale taxonomic inventory in order to screen a large number of species subsequently for natural products of potential pharmaceutical interest (Aldhous 1991; Roberts 1992; Blum 1993; Coughlin 1993; Caporale 1996; Zebich-Knos 1997). This was followed up by subsequent collaborations between INBio and other stakeholders, including Cornell University, Harvard Medical School, the University of Michigan, the Broad Institute, and the Novartis Institutes for Biomedical Research (Weiss \& Eisner 1998; Dalton 2006). While INBio's parataxonomist program has become a global model for citizen science and has increased sensibility for biodiversity and taxonomy in local communities (Janzen 1991; Kazmier 2017; Niesenbaum 2019), the approach overall has not produced the expected results in applied terms (Mullin 2008; Pennisi 2013). With the discontinuation of these programs and the lack of funding, INBio had to cease its role as a leader of taxonomic research in Costa Rica and render its natural history collections to the National Museum, from which part of them actually originated. Similar projects in other countries, such as the Iwokrama Fungal/Plant Bioprospecting Project from 2000 to 2003 in Guyana (Pingal 2017), did not yield commercially exploitable results either. These cases demonstrate that the idea of "... making biodiversity profitable ..." or "... cashing in on the rich coast ..." (Blum 1993; Dalton 2006) is misguided thinking. Indeed, many pharmaceutical companies have stopped their natural product research and shifted towards combinatorial chemistry (Mullin 2008; Beutler 2009). This is not to say that organisms such as fungi do not have potential, quite to the contrary (Hyde et al. 2019). However, we taxonomists should maneuver ourselves out of a position where we have to justify the importance of taxonomy with envisioned applications of a limited number of species that may not have been discovered yet.

From 2002 to 2004, the NSF-funded project TICOLICHEN-The Costa Rican Biodiversity Inventory (NSF DEB-0206125; Lücking et al. 2004) collaborated with INBio in forming national expertise in tropical lichen taxonomy. However, inspite of successful training of resident experts and numerous published results, including the description of 105 species (out of a total of 641 treated), five genera, one family and one order new to science (Chaves et al. 2004; Nelsen et al. 2006; Rivas Plata et al. 2006; Aptroot et al. 2006, 2008; Lücking et al. 2006, 2007, 2008; Sipman et al. 2012), with the demise of INBio as a focal point for taxonomy, the job situation for such talent in taxonomy has continued to look grim, losing the opportunity of a cascading effect of newly formed experts to educate further generations of taxonomists in their country. A follow-up, also NSFfunded project covering a much more extended area, Neotropical Epiphytic Microlichens (NSF DEB-0715660), trained 452 students in 42 workshops in 16 countries the skills of taxonomy and related fields, including molecular phylogeny and multivariate community ecology, with over 50 thesis works supervised (International Innovation 2012). However, there is mostly little or no scientific infrastructure to further foster this talent, let alone providing jobs, particularly in Central American countries such as El Salvador or Nicaragua.

Taxonomy as a "finite" science. In order to assess the importance of taxonomy for science and society, one has to distinguish two types of taxonomists: those who chiefly generate taxonomic knowledge, the "taxonomic providers", and those who chiefly apply it, the "taxonomic users" (Sharma 1993; Ebach et al. 2011). Users apply identification tools, including field guides, to "learn" species as means to an end, for instance to perform community mapping to assess the potential environmental 
impact of infrastructure and industrial projects. Providers are the genuine taxonomic specialists, who are not only able to identify species but also to describe new species in a knowledge-based context and, most importantly, to assemble the identification tools used by others. The immediate importance of taxonomy, both in a scientific and a societal context, is to catalog species, provide effective identification tools, and act as expertise in taxon identifications. It is the taxonomic providers that require a steady support for permanent and consistent output.
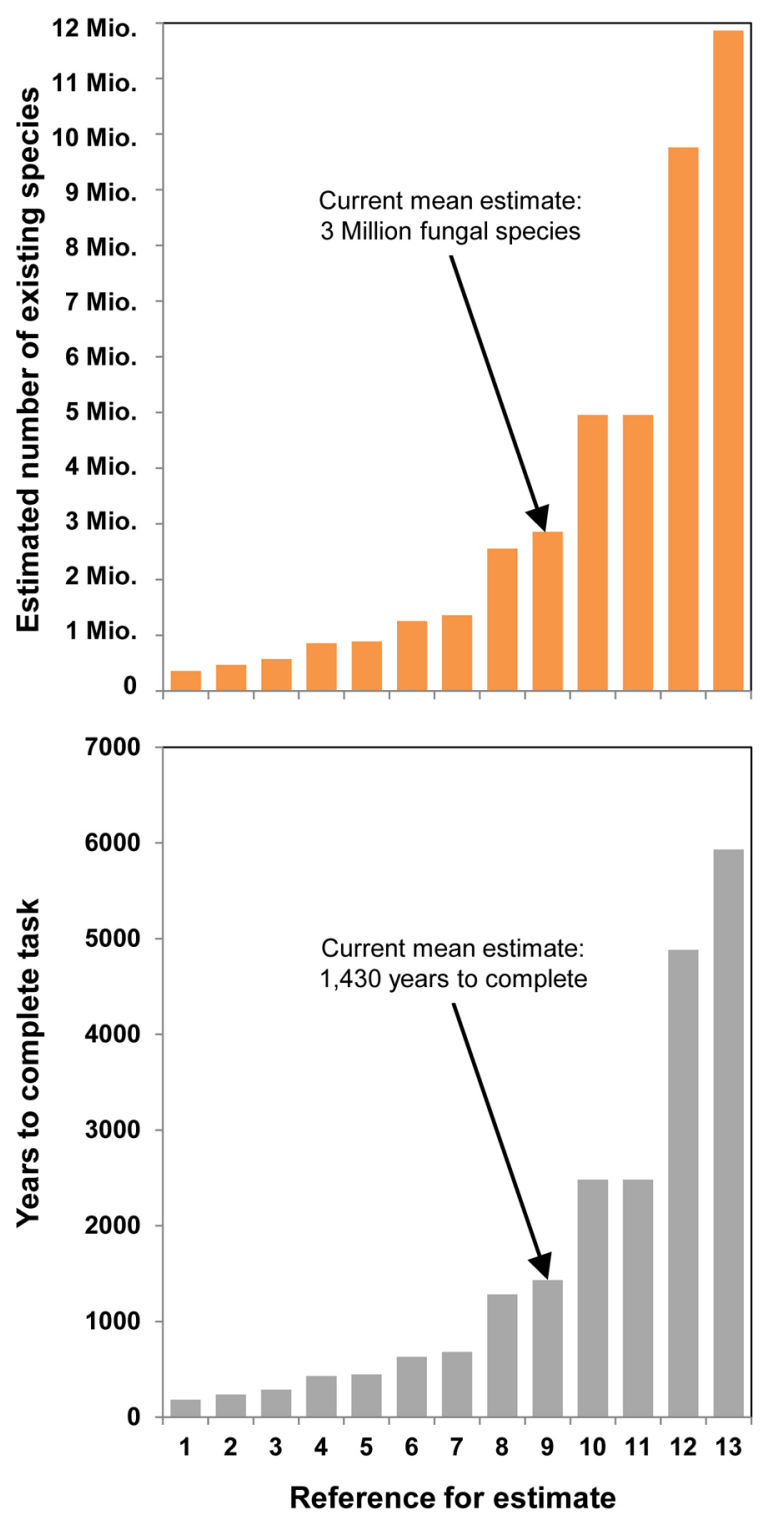

FIGURE 1. Estimated time to complete the inventory of fungal species, given a current maximum rate of 2,000 new species per year and based on different global richness predictions: (1) May (2000); (2) Mora et al. (2011); (3) Schmit \& Mueller (2006); (4) Hammond (1992); (5) Rossman (1994); (6) Mora et al. 2011 (adjusted according to Hawksworth \& Lücking 2018); (7) Hawksworth (1991, 2001); (8) Pascoe (1990); (9) Hawksworth (2012) and Hawksworth \& Lücking (2018); (10) Hawksworth \& Rossman (1997) (in Hawksworth 2001); (11) O'Brien et al. (2005); (12) Cannon (1997); (13) Wu et al. (2019).
There is also a third type, namely "species (co-)authors", who are mostly not taxonomists at all but who contributed to species discoveries in some form. "Species authors" can certainly not be equaled to taxonomists, as proposed by Joppa et al. (2011) or Costello et al. (2013a), claiming that taxonomy is at an all-time high. For instance, there are close to 18,000 authors of fungal species. Of these, $42 \%$ have (co-)authored a single species, and 70\% up to four species. If we define taxonomy as professional exercise, a true taxonomist must have named multiple species. For instance, only $30 \%$ of authors of fungal species have named 5-9, only 18\% have named 10-24, and only $10 \%$ have named 25 or more species. How many species named makes a true taxonomist? Arguably, expert taxonomists should both be prolific in species descriptions and provide monographs and identification tools. Certainly, only a fraction of the authors analysed by Costello et al. (2013a) fulfil these two criteria.

Notably, the role of taxonomic providers is not static through time but has a path with an end. Formally beginning with Linnaeus $(1753,1758)$, the Tree of Life was essentially unknown and cataloguing species was the most important task for taxonomists. It still is, but the number of species is not infinite. While we do not know the exact number and have only estimates as to how many species still await discovery (Mora et al. 2011; Hawksworth \& Lücking 2018), the task to discover and describe them has an end (hopefully not through extinction). The same applies to identification tools, which need to be adjusted to accommodate new discoveries and changes in classifications and also require technological updates: once all species are catalogued and technological options are exhausted, identification tools will be "done". It should thereby not be overlooked that advanced tools such as molecular barcoding or shape recognition only work after knowledgeable taxonomists have provided the fundamental groundwork first (Carvalho et. 2007, 2008). Automatism does not replace taxonomy; it can only be successfully employed once the taxonomy for a group has been completed. When it has, taxonomy as a separate discipline of science becomes indeed largely obsolete, leaving just the third component, expert identifications, which can be performed by well-trained taxonomic users or, where possible, with partly automated tools.

While this path is indeed finite, we cannot overlook that for many species-rich groups such as fungi, arthropods, or microorganisms, we are still far from its end, contrary to some recently published analyses (Costello et al. $2013 \mathrm{a}, \mathrm{b})$. In fungi, at the current maximum rate of 2,000 new species per year (Hawksworth \& Lücking 2018), mycologists would require between 180 and 5,930(!) years to complete the task, for the most conservative and most progressive estimates, respectively, and 1,430 years for a mean estimate of 3 million outstanding species (Fig. 1). 
Dubbing the splitting of presumably known "species" into more narrowly defined taxa "taxonomic inflation" (Isaac et al. 2004) may give the wrong impression that part of this taxonomic exercise is unnecessary. However, revisionary approaches that lead to splitting are no different from new species discoveries and they may unravel dramatic levels of previously unrecognized diversity. Such is the case with the basidiolichen genus Cora, which used to be considered comprising a single species and currently counts 189 (Lücking et al. 2014, 2017).

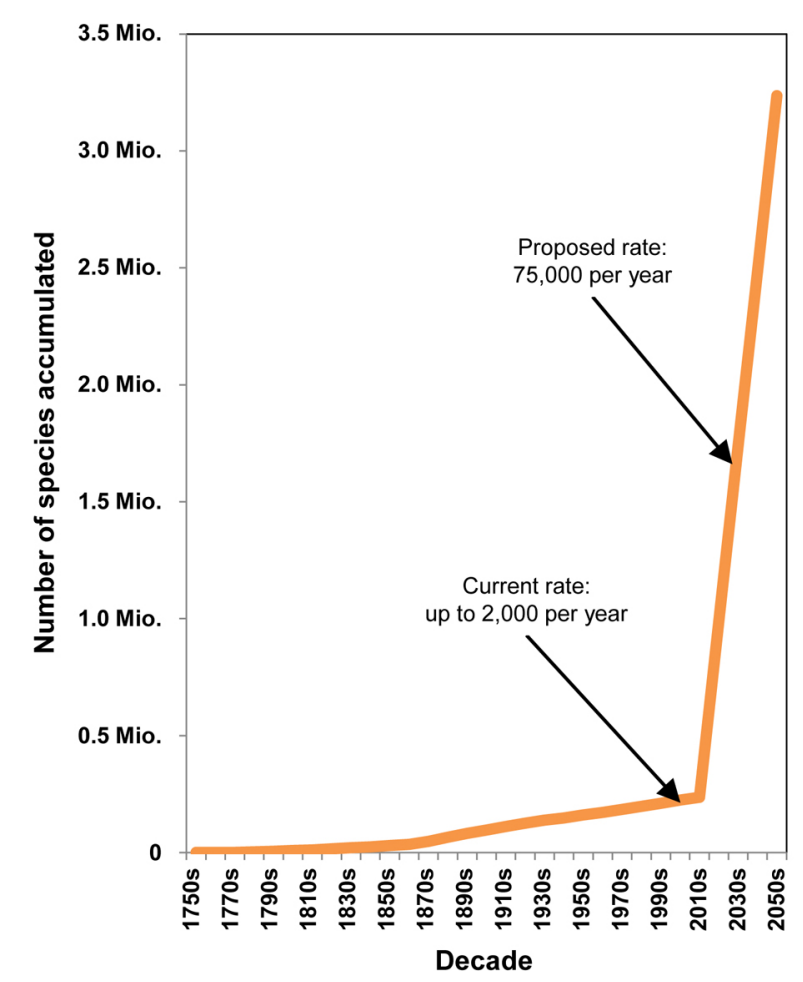

FIGURE 2. Historic, current and future proposed accumulation of catalogued fungal species assuming a much increase annual rate by a dedicated workforce of 300 full-time taxonomists, envisioning a completion of an additional 3 million species by 2060 .

The consideration of taxonomy being a finite branch of science is important as it limits the necessary investment of resources. Societies do not need to support expert taxonomy forever. The amount of money to be spent to maintain a sufficiently strong workforce of taxonomic experts, until all species are catalogued, and comprehensive and effective identification tools are in place, can be calculated, even if we are still far away from this goal. Mora et al. (2011) predicted a total of 8.7 million species based on 1.2 million already described, i.e. an outstanding balance of 7.5 million. Their calculations are considered conservative, as the numbers of known species to compute the global estimate were about $30-50 \%$ too low (Bass \& Richards 2011; Hawksworth \& Lücking 2018; Roskov et al. 2019). The outstanding balance is likely over 10 million. In fungi including lichens, the most prolific taxonomists have catalogued thousands of species over their career (see below), and a full time taxonomic expert provider can likely catalogue 10,000 species on average over a career of 40 years ( 250 per year or five per week), if that person is not doing anything else. Thus, with a mean estimate of 3 million outstanding fungi (Hawksworth \& Lücking 2018), this gap could be closed by 300 exclusive fungal taxonomists in 40 years, increasing the current maximum rate of 2,000 to 75,000 species per year (Fig. 2).

Assuming similar figures for other groups of organisms and a number of 10 million species still to be catalogued, this would require maintaining 1,000 full-time taxonomic experts over a period of 40 years, a number similar in magnitude to the number of currently active expert taxonomists (Gevin 2002). Such a much increased rate does not seem to be exaggerated, provided that this army of taxonomists is allowed to focus entirely on the task at hand and using advanced methods for rapidly cataloguing species (Mayo et al. 2008; Clark et al. 2009; La Salle et al. 2009; Deans et al. 2012; Riedel et al. 2013; Lücking et al. 2017; Meierotto et al. 2019). With a balanced global distribution of taxonomists and an average salary cost of $\$ 50,000$ per year per taxonomist, this would amount to $\$ 2$ billion in total. Giving each taxonomist a dedicated technician for collections and laboratory work, at an average salary cost of $\$ 40,000$, would add another $\$ 1.6$ billion. Expenses for material and laboratory costs (e.g. to generate molecular data; Padial \& De la Riva 2007) and to properly maintain voucher collections may add another $\$ 400$ million; for instance, assuming an average of ten molecular barcodes per species at a cost of $\$ 2$ would add \$200 million when using traditional Sanger technology, but likely much less when employing next-gen amplicon sequencing (and who knows what's to come within the next decade). Overall, such an ambitious endeavor could be realized with a current value of $\$ 4$ billion, a figure that is remarkably close to the $\$ 3$ billion proposed by the All Species Foundation (Bank 2002; Gevin 2002), which aimed to catalogue all species within a time frame of 25 years but was discontinued in 2007. An expenditure of $\$ 4$ billion, over a time span of 40 years, would translate to $\$ 100$ million per year globally. The current global gross domestic product (GDP) amounts to about $\$ 80$ trillion per year, which means that a continued, dedicated support for full-time expert taxonomists for the next 40 years would result in a cost of $0.0001 \%$ of the GDP. Countries spend between $0.07 \%$ and $4.3 \%$ of their annual GDP on research and development (Wikipedia 2020), i.e. a continued support for taxonomy for the next few decades, until all species have been catalogued, would require a truly negligible amount. Also, one does not have to argue with missions to outer space to underline the dramatic neglect of support for getting to know our own planet (Wheeler 2010). The solution is much closer: 
global military spending was around \$1.8 trillion per year in 2018 (SIPRI 2019), about 2\% of the GDP. If annual global military spending would be reduced to $99.995 \%$ and the money saved spent for cataloguing all species on Earth, taxonomy would be fine. If military spending would be stopped as a whole, and all that money invested into education and science, imagine the paradise our planet would be!

Appreciation (and the lack thereof) of taxonomy in (and as) science. One striking problem of taxonomy is not its perceived outdatedness but the notorious lack of formal appreciation in biodiversity research and biology in general (Dubois 2003). It is no question that taxonomy is needed and used extensively, but it is notoriously undercited, more so than any other scientific discipline (Werner 2006, 2009; Agnarsson \& Kuntner 2007; Ebach et al. 2011). For instance, the best-known fungal model organism, Neurospora crassa, was first described by Shear \& Dodge (1927). Google Scholar [https://scholar. google.com] gives 344 citations for that work which, for a time span of 92 years, translate into an impact factor of 5.6. The Web of Science [http://apps.webofknowledge. com] lists 1,813 publications under the topical key word 'Neurospora crassa'. Many of these papers have a much higher citation count than the original description from 1927, within a much shorter time period. For instance, the publication of the $N$. crassa genome (Galagan et al. 2003 ) and the much cited work on species recognition and concepts in fungi using $N$. crassa as a model case (Taylor et al. 2000) have between 1,100 and 1,650 citations in the Web of Science Core Collection and in Google Scholar, translating into impact factors of between 85 and 150! Of course, a species description is by no means comparable to such advanced studies, but the latter essentially capitalize on taxonomy, which should be reflected in citing the protologue as often as possible (Werner 2006; Agnarsson $\&$ Kuntner 2007). Both of the aforementioned studies do, but much more often than not this is not the case, as shown by the over 1,800 papers relating to $N$. crassa but apparently less than $20 \%$ citing the original taxonomic study.

Van der Velde (2001) argued that taxonomists are implicitly cited each time a taxon name is cited. This statement could not be more wrong. Naming Darwin is not the same as formally citing his work. For instance, the yeast Saccharomyces cerevisiae was originally established by the French mycologist Jean Baptiste Desmazières [1786-1862] under the genus name Mycoderma Pers., as $M$. cervisiae [sic] (Desmazières 1823, 1827) and subsequently combined into the new genus Saccharomyces by the Prussian botanist Franz Meyen [1804-1840], as $S$. cerevisiae [sic] (Desm.) Meyen (Meyen 1838). According to Van der Velde (2001), the authors of that taxon had
43,403 citations in the Web of Science at the time (then ISI Web of Science). To put it mildly: this is pure nonsense. Of course neither of the two authors has any such citations, not only because because their work was not actually cited but also because the Web of Science currently only goes back to 1900 (Core Collection only to 1945). What Van der Velde (2001) counted was only the number of papers citing the name Saccharomyces cerevisiae, corresponding to the case outlined above. The credit to the taxonomists is thereby zero. Such blatantly misleading statements, moreover, prominently published in a journal such as Nature, are a bad service to the taxonomic community.

A similar problem occurs particularly in multispecies ecological and biogeographical studies, which presumably use proper identification tools to identify species, but often fail to cite these tools or to collaborate with taxonomists from the onset (Bortolus 2008; Vink et al. 2012; Halme et al. 2015). In contrast, original works on scientific theories or tools are routinely cited, properly reflecting their importance in terms of citation count and impact factor. For instance, the book first mentioning the term "sixth extinction", The Sixth Extinction: Biodiversity and it's Survival by Leakey \& Lewin (1996), has been cited over 250 times according to Google Scholar, corresponding to an impact factor of 16. Methodological papers typically have citation counts any taxonomic work can only dream of. Thus, the recent update on the most widely used application for molecular clock analyses, BEAST (Drummond et al. 2012), has already 5,725 citations in the Web of Science Core Collection and 7,381 in Google Scholar, translating into an impact factor of between 1,200 and 1,600. This is of course in large part explained by the actual "impact" of such works in terms of broad interest, but is also caused by the obligation of journals to properly cite such methodological papers. Following a proposal by Werner (2006), some journals such as Phytotaxa and its sister journals attempt to remedy this problem for the field of taxonomy, by forcing authors to properly cite taxonomic works after each species name, but since this effort is limited to a few taxonomic journals, the effect is minor. High impact journals have strong limitations on the number of citations allowed, and so for papers that used taxonomic resources in the process, such references are the first to be dropped, if at all initially recorded.

Even if a work is properly cited, it might still suffer from the caveats of modern science metrics. A prime example is the aforementioned ICN, the code governing the nomenclature of plants, fungi, algae and similar organisms. The ICN is a fundamental tool regulating the naming part of taxonomy, and its proper application is an essential component of the work of taxonomic providers. The current ICN, the Shenzhen Code (Turland et al. 2018 ) is one of the most cited taxonomic reference works 
in contemporaneous biodiversity research, with already around 800 Google Scholar citations, corresponding to an impact factor of 1,200, approaching a level of highly cited methodological papers. It is, however, not indexed and therefore has zero citations in the Web of Science, one of the principal sources to compute publication metrics. This is a major impediment to taxonomic literature, because comprehensive revisions and monographs, the most important taxonomic tools, cannot be published in indexed journals and are usually not separately indexed, and hence their fundamental importance to science is not metricized. While Elsevier's Scopus and Clarivate's Web of Science (former ISI Web of Knowledge) focus on peer-reviewed journals and conference proceedings, the possibility to index book series and books does exist. However, this happens only selectively and only covering recent publications (Torres-Salinas et al. 2014; Mann 2015). The freely available Google Scholar and Google Books are somewhat mitigating this problem (Cronin \& Sugimoto 2014), but are far from complete and structured searches and analytics are cumbersome.

Another factor is the erroneous perception that taxonomy is not hypothesis-driven, therefore not "scientific", and does not advance methodologically (Sharma 1993; Korf 2005; Ebach et al. 2011). This could not be further from the truth. Just as any other branch of science, taxonomy continuously improves and reinvents itself along with the development of new concepts and technologies (Korf 2005; Sluys 2013). Milestones in taxonomy include the application of the microscope, quantitative numerical taxonomy and Hennigian cladistics, computerized interactive identification tools, genealogy-based species delimitation, machine-learning and feature-recognition tools, and approaches to rapidly cataloguing new species, among many others (Mayo et al. 2008; La Salle et al. 2009; Deans et al. 2012; Riedel et al. 2013; Lücking et al. 2017; Meierotto et al. 2019). Indeed, modern taxonomy is a far cry from Linnean taxonomy, even if it uses the same nomenclatural principles (Lücking 2019). But just as pipetting liquids is basic work in laboratory-based research, the descriptive approach to catalogue species is still a basic element of taxonomy. Taxonomy is likely the most tested, hypothesis-driven branch of the biological sciences (Wheeler 2004; Sluys 2013). Very rarely is a scientific experiment repeated over and over again to test its validity, but species are. Species are hypotheses, and in modern tools such as the UNITE database for curated fungal ITS barcoding sequences (Abarenkov et al. 2010), they are properly denominated thus. It does not matter whether species hypotheses are being established on phenotypical grounds or using the most advanced genomic approach. Each and every time voucher specimens and/or their associated data are being analyzed, a species hypothesis is established, tested, and if necessary adjusted. For many species that may happen rarely, but for others it may occur hundreds of times over. Thus, taxonomy is as rigorous a hypothesisdriven approach as any other branch of science.

Conclusion. A few steps require implementation to properly reflect the importance of taxonomy in science and society. First and foremost, taxonomists must accept their responsibility in being prolific generators of taxonomic knowledge; if they are not ready to do that, they should not take positions away from others that do. Also, taxonomists themselves must sell their products better. This is not a consequence of capitalism, but intrinsic to human nature itself. One can produce the best product on the market, but without proper advertisement, it will not sell. There are ways to make alpha-taxonomic publications more attractive to a broad readership, and taxonomic journals do now discourage 'naked' species descriptions that are of interest to specialists only.

Amateurs provide important contributions to taxonomy but are often unaware of novel developments and science policies, therefore the integration of amateur and professional taxonomy, and furthermore citizen science, as well as balancing global taxonomic expertise and methodology more equally over the globe, is key to another taxonomic renaissance. If that happens, then maybe society and policy makers can be convinced to make an effort for a consolidated, long-term support for a dedicated taxonomic workforce to catalogue the remaining millions of species within the next decades. Along with that, it may be too much to hope that humanity comes to its senses and shifts its current vision of nature as a "service unit" to nature as an intrinsic feature of our planet that should be conserved without measuring its potential value.

Taxonomic works must be properly incorporated into the machinery that establishes scientific impact scores and other metrics, with two clearly defined measures: (1) journals must encourage authors to properly cite taxonomic works, and (2) taxonomic works must be properly indexed, including retroactively. There is no reason why only regularly published journals can and should be indexed and used as the basis for impact factors and similar calculations.

\section{An increasing methodological gap in alpha taxonomy: challenge or opportunity?}

Technological advancements of taxonomy. Taxonomy continuously reinvents itself with new conceptual and technological approaches (Korf 2005; Watson et al. 2015; Reboleira \& Enghoff 2016). Unfortunately, this generates an ever-growing divide between taxonomists working in 
different situations at a global level, consisting of two components: (1) a resource-based technological gap and (2) a methodological and conceptual knowledge gap. Many potentially prolific taxonomists do not have access to advanced methods such as molecular sequencing; if they have, or have free access to data through repositories such as GenBank (Sayers et al. 2019), they may lack the training to properly work with such data. This is particular apparent in biodiversity-rich countries and for amateur taxonomists.

Cataloguing species produces formal names, together with diagnostic descriptions and other associated data. The core elements of formal descriptions do not differ markedly from Linnean taxonomy almost three centuries ago, although the format and layout has evolved considerably, as has the technology underlying species discoveries. Before the advent of molecular methods, which are entering another new era with genomic approaches, or phylogenomics (Rokas et al. 2007; Zhang et al. 2017; Grewe et al. 2018; Koch et al. 2018), it was first the light microscope, later the electron microscope, and eventually the various instruments to analyze secondary compounds, that shaped advances in taxonomic approaches, not only in lichenology or mycology. Also, ad hoc species assessments were replaced by quantitative analytical methods such as numerical taxonomy or Hennigian cladistics, with an ever increasing set of tools for phylogenetic analysis of molecular sequence data (Sokal \& Sneath 1963; Sneath \& Sokal 1973; Funk \& Stuessy 1978; Platnick 1979; Kitching et al. 1998; Zhao et al. 2015).

Use of these technological advances in cataloguing species is often equated with quality or "science", with the consequence that taxonomists not using these methods are considered to produce low-quality or non-scientific output. Lately, the advent phylogenomics has even led to statements by reviewers of manuscripts or project applications to consider Sanger sequencing outdated (Hert et al. 2008; own experience by the author, more than once). However, quality and scientific foundation of taxonomic work does not depend on methods but on the conceptual approach, attention to detail, and knowledge base (Darlington 1971). Some of the taxonomy nowadays published is of questionably quality, even using the most advanced molecular approaches, whereas so-called "old school" taxonomist, just armed with a good microscope, may still do a better job in describing new species. Also, the best method is not usually the newest, but the one that best serves to answer a question.

Well-thought biodiversity inventory projects in grossly understudied areas that include training of local expertise and establishing new, well-identified reference collections, supported by molecular barcoding through standard Sanger sequencing, are nowadays routinely rejected when they do not contain "novel methodological approaches" (including a recent experience by this very author). "Novel" in this context translates into phylogenomics. It is certainly true that phylogenomics represents a leap in taxonomy and systematics, but its background is often misunderstood. Phylogenomics is, by and large, the same as phylogenetics, but performed with a substantially larger amount of data. To put it simply: if phylogenetics is polling, phylogenomics is election day. Polling is not accurate, but its error margins are known (Jennings \& Wlezien 2018). The ratio between electoral and polling size is about five orders of magnitude. Statistically speaking, "phylogenetic polling" is thus substantially more reliable. Fungi have an average genome size between 30 and 50 million bases (Mohanta \& Bae 2015), but in phylogenomic approaches only a portion of this information is used (Delsuc et al. 2005; Grewe et al. 2018; Widhelm et al. 2018). A typical multimarker phylogenetic analysis may employ three to five markers with a concatenated alignment size between 2,000 and 5,000 bases, resulting in a ratio two to three orders of magnitude in most cases. A caveat is that "phylogenetic polling" is not random with respect to the entire genome, but it certainly has not become useless or outdated in the light of phylogenomics.

Indeed, there is nothing wrong in cataloguing new species even based on phenotype data only, even in a time where the entire genome of a species can be easily sequenced. On the contrary, any approach generates a species hypothesis, and phenotype descriptions are an integral part (Wheeler 2018). However, the approach should be appropriate for the group under study. For most, if not all fungi including lichens, a compound microscope is still a useful, in fact indispensable tool. The comprehensive microscopic surveys produced by the German amateur lichenologist Felix Schumm, in collaboration with taxonomic experts, on lichens of all groups and geographic regions (Schumm \& Aptroot 2010, 2012a, b, 2019a-d; Aptroot \& Schumm 2011), are an invaluable source to interpret phenotype characters in an evolutionary contexts when analysed on the background of phylogenetic relationships. The electron microscope has largely gone out of fashion in fungal taxonomy, although it can provide useful ultrastructural data and it can reveal taxonomically important characters difficult to assess otherwise (Celio et al. 2006). Where chemotaxonomy is important, proper tools are required, at a minimum thinlayer chromatography equipment (Orange et al. 2010; Schumm \& Elix 2015), although advanced approaches such as liquid chromatographymass spectrometry are a more precise alternative (Olivier-Jimenez et al. 2019). Molecular analysis is particularly useful in disentangling species complexes and poorly or wrongly understood morphospecies or to place taxa with novel phenotypes 
into a systematic context. Other fungi groups require specific approaches via culturing and physiological assessments or specific tests. Hence, quality of science is not determined by the tools per se, but how adequate the tools are for the group in question (Darlington 1971). The proper approach should be the "minimum approach" necessary for a specific problem in a particular group. Therefore, the level of access to the required tools determines the group that can be taxonomically studied.

While the number of expert taxonomists is dwindling, in almost any group of organisms, only a part of the remaining taxonomists has advanced tools at their disposal and/or have proper training to deal with data such as molecular sequences. This divide is found to some extent between professionals and amateurs but especially between so-called "developed" and biodiversity-rich countries. Thus, not only is the diversity of organisms unequally distributed across the globe, but also the potential to tackle the taxonomy of specific groups, and not in a correlated manner. This may result in inadequate approaches to the taxonomy of particular groups in places where the such groups are rich in species but the conditions for proper methodological approaches are not given.

Good taxonomy: the result of "nature" plus "nurture". An often even larger problem than the methodology gap is the lack of proper education in scientific concepts and approaches. Good taxonomy requires both talent and training. Pattern recognition and memory capacity are two fundamental requirements for taxonomists that are mostly hard-wired into the human brain. Such talent is independent of geographic and political boundaries but needs to be properly recognized and nurtured. Conceptual and formal approaches to taxonomy need to be learned, such as the philosophy behind species concepts, the analytical tools to assess data structures, or the rules of nomenclature. For instance, many taxonomists in biodiversity-rich countries (and non-taxonomists world-wide) have a naive approach to molecular barcoding, thinking that a similarity match identifies a species. A particular component of such education is self-criticism, the capacity of questioning and testing one's own conclusions. If someone can publish the finding of the lichen Peltigera sp. as a novel report for Colombian mangroves and discuss this in the context of bioindication of environmental changes, when the actual taxon at hand is a nicely depicted bromeliad Tillandsia usneoides (Avendaño-Remolina et al. 2000; ÁlvarezLeón et al. 2014), then there are problems at several levels, including basic scientific education, peer review, and editorial scrutiny. The training to avoid such mishaps should form a routine part of university curricula, not only in the biological sciences. However, this is often neglected, particularly in biodiversity-rich countries which focus their university curricula towards applied research (Barber et al. 2014). Associated with that problem is the lack of perspectives on the job market (Agnarsson \& Kuntner 2007). Capacitation through international collaboration, such as the many examples mentioned above, may help, but if the regional educational and scientific infrastructure is not substantially improved, such efforts are ultimately futile.

Overall, these challenges also provide opportunities. While traditional taxonomy used to be a one (wo-)man show, with authors from Europe and NorthAmerica working in single authorship on the taxonomy of organisms in biodiversity-rich countries (see below), there is a strongly increasing interest in collaborative approaches that not only provide synergy but also mitigate the methodology gap by providing mutual training and support, at least for the duration of a project. The same applies in increasing collaborations between professionals and amateurs, including citizen science. One very successful approach is the concept of parataxonomy, training of citizens in collecting specimens and data for research (Janzen 1991; Hallwachs et al. 1993; Kazmier 2017; Niesenbaum 2019). This concept integrates non-scientists with excellent local knowledge and access to natural environments with taxonomists providing the expertise and methodological know-how. Another initiative could be targeted training as part of projects using advanced methodologies, by inviting a student or colleague from abroad to participate in specific aspects of the study, with a mutual agreement that his or her home institution logistically supports longterm implementation of the method, e.g. by installing a proper laboratory and providing a permanent technician. Collaboration that is intended to result in sustained benefit-sharing is not a one-way street.

Conclusion. Scientific quality of taxonomic work is not determined by using the most advanced methods but by a sound conceptual approach, a good knowledge base and by using the methods proper to the question and group under study. Just as phenotype-based taxonomy can be of outstanding quality, and some amateurs surpass professionals in that respect, molecular and genomebased studies can be abysmal. Manuscripts and project proposals should not be judged based on how novel the methodology is, but based on their overall quality. Otherwise, a substantial workforce of talented taxonomists who simply have no access to genome sequencing will continue to be scared away. Exactly these represent largely untapped potential when it comes to assist laboratoryand computer-based phylogeneticists in interpreting their results in a holistic evolutionary context.

Good taxonomists require both talent and training, and university curricula or other media to train taxonomists should implement measures to both recognize such talent 


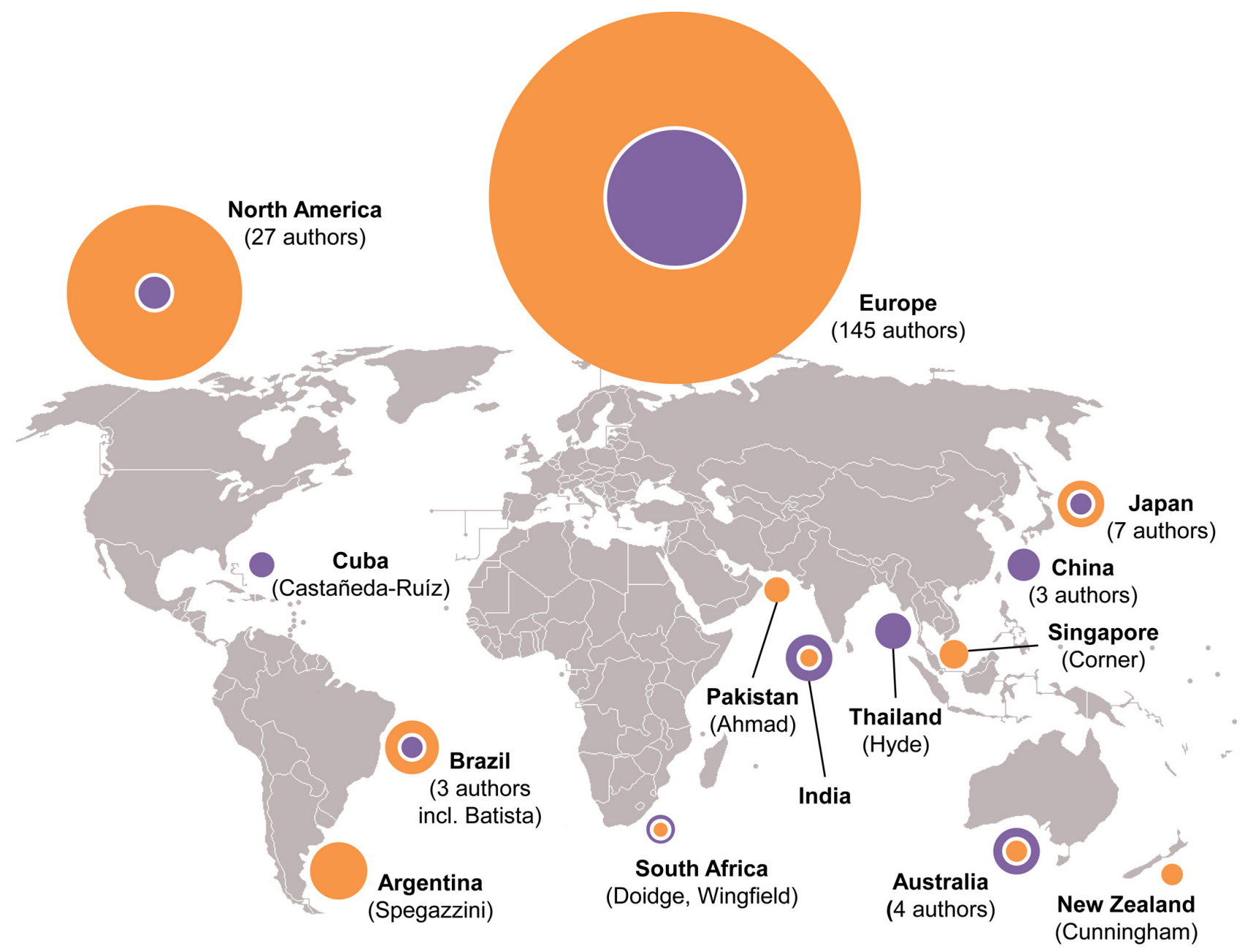

FIGURE 3. Global distribution of the 200 most prolific fungal taxonomists, responsable for nearly half of all approximately 360,000 species names described (Index Fungorum 2020; cut-off point: December 2017). Orange: historic and recent authors that have passed away (75\%); violet: authors still alive and active (25\%). The area size of the circles is proportional to the species named by these authors. Note the overall heavily unbalanced distribution of both described species and authors towards Europe and North America but the more balanced situation when only taking into account active taxonomists. For detailed information, see Table 1). The base map was modified from Wikipedia [https://upload.wikimedia.org/wikipedia/commons/e/e8/World_blank_ map_countries.PNG].

and to provide proper formal training, especially in biodiversity-rich countries. A solid future job market is a necessary condition to incentivize talents in taxonomy to follow that path. Taxonomic talent has no geographic or political boundaries and many potential good taxonomists are to be found among young students in biodiversityrich countries where most of the uncatalogued species occur. International collaborative projects are the best approach to discover and nurture such talent. Biodiversity-rich countries have the responsibility to provide the infrastructure for proper scientific education and a corresponding job market. After all, rather than pointing out that most of their biota has been inventoried by foreign researchers, these countries long had the potential to surpass Europe and North America in forming a proper taxonomic workforce to undertake this endeavor, implementing advanced technologies in a timely manner, with the advantage of having the biodiversity at their fingertips.

\section{The Nagoya Protocol: improvement or impediment to the science of taxonomy?}

Taxonomy, colonialism and the Convention on Biological Diversity. The issues raised in the previous chapter become particularly obvious when comparing the concentration of taxonomic expertise with the geographic distribution of biodiversity hot spots, which harbor the highest number of unknown species still to be catalogued (Myers et al. 2000). For instance, the over 320,000 known 
fungal species names were established by about 18,000 authors (Index Fungorum 2020). The 200 most prolific authors (1\%) account for nearly $50 \%$ of the names; among these, only few originate from biodiversity-rich countries, largely Cuba, Brazil and India (Fig. 3; Table 1). In addition, rather than representing a diverse taxonomic workforce as in Europe and North America, it is mostly individuals that stand out as prolific species cataloguers in these countries, such as the Brazilian Augusto Chaves Batista, the Italian-born Carlos Spegazzini, or the Cuban Rafael Castañeda-Ruíz.

The striking mismatch between biodiversity-rich tropical countries and the concentration of taxonomic expertise in Europe and North America is a well-known phenomenon (Giangrande 2003; Drew 2011; Smith \& Figueiredo 2011; Habel et al. 2014). Much of this can be attributed to (post-)colonialism (Figueiredo \& Smith 2010), but that does not seem to apply to Latin America. Comprehensive studies on lichens in this region commenced just after most of Latin America had become independent in the 1820s (Fig. 4). While until the late 1920s, these were exclusively performed by European and North American taxonomists, Spain and Portugal, as the two countries occupying most of the area during colonial times, played no role in taxonomic inventories of lichens during this century-long period, with over 400 papers on record (online Supplementary file). The outcome, nevertheless, was the same: information was published, and collections deposited in European and North American journals and herbaria, inaccesible to researchers in the countries of origin.

In order to better control such practices, biodiversityrich countries have long implemented regulations for collecting specimens, performing research, and the deposition of reference material and data. Unfortunately, these regulations were, and still are, often neglected or ignored, also because little attention was paid to this problem. Two developments have changed this. For one, there was the boom of natural products screening (Snader \& McCloud 1994; Raffauf 1996; Wildman 2003; Harvey 2007; Lahlou 2007; Koehn 2008). The first major international collaboration to provide a biodiverserich country with revenue resulting from potential pharmaceutical applications of its biodiversity, and to use this revenue to study and protect said biodiversity, was the aforementioned agreement between Merck and INBio in Costa Rica in 1991 (Aldhous 1991; Blum 1993). Following this example, similar projects emerged elsewhere (Suffness et al. 1995; Sittenfeld et al. 1999; Soejarto et al. 2004; Dalton 2006; Lewis \& Ramani 2007). Then, there was the advent of molecular phylogenetics (Samuels \& Seifert 1995; Crous 2005). Both the potential use of natural products and the access to genetic resources suddenly put taxonomy in the spotlight, under the misguided impression that discovery of new species would bring wealth through potential applications of their chemical and genetic makeup. Cases of biopiracy, the improper utilization of traditional knowledge or genetic resources, are well-documented (Merson 2000; Zakrzewski 2002; DeGeer 2003; Hamilton 2006; Dwyer 2008; Wyatt 2014; Goyes \& South 2015; Aoki 2017; South 2017), although this issue is complex and controversial (Chen 2006). While the discussion of societal and industrial ethics regarding the utilization of biodiversity is important, it should not affect basic research such taxonomy and systematics; yet it does (Grajal 1999; Watanabe 2015; Prathapan et al. 2018). Disputable cases of biopiracy are few in comparison with the thousands of taxonomists and other biodiversity researchers that have to deal with the consequences of black sheep in applied sciences.

The Convention on Biological Diversity (CBD) was the first international agreement to regulate access to and research on genetic resources and biotechnology and resulting benefit sharing (Rubin \& Fish 1994). The Nagoya Protocol on Access to Genetic Resources and the Fair and Equitable Sharing of Benefits Arising from their Utilization (henceforth: Nagoya Protocol) from 2014 implements the objectives of the CBD, focusing specifically on access to genetic resources, biotechnology, and associated traditional knowledge (Young 2013; Oberthür \& Rosendal 2013; Rabitz 2015). It is often misunderstood that the Nagoya Protocol implies new national regulations that did not previously exist, when in fact most parties to the protocol had such regulations in place even long before the CBD, and the Nagoya Protocol is only an instrument to implement international control on these regulations as agreed upon in the CBD more than twenty years prior.

As outlined above, the Nagoya Protocol does not explicitly address taxonomic research. Its principal aim is to regulate utilization of biodiversity in applied research for revenue gain, through genetic resources and biotechnology. In practice, however, the bulk of research affected by the Nagoya Protocol is basic science in the fields of taxonomy, systematics, ecology, biogeography and conservation (Grajal 1999; Watanabe 2015; Prathapan et al. 2018). For instance, of 3,403 studies performed on Latin American lichens (and lichenicolous fungi) between 1751 and 2019 (online supplementary file), $87 \%$ can be classified as basic research (77\% taxonomy and systematics and related fields, 10\% ecology and biogeography and related fields), another $6 \%$ correspond to areas with some applied aspects but no revenue gain (biomonitoring, conservation, biodeteroriation), and only $7 \%$ have applied and potentially revenuegaining aspects (biotechnology, biochemistry, culturing, ethnolichenology; Fig. 5). More than half of the taxonomic and systematic studies have been performed since 1995, 
TABLE 1. The 200 most prolific authors and co-authors of fungal species, based on Index Fungorum (2000; cut-off point: December 2017).

\begin{tabular}{|c|c|c|c|c|}
\hline Name & Abbreviation & Country & Species & s Lifetime \\
\hline Saccardo, Pier Andrea & Sacc. & Italy & 6052 & $1845-1920$ \\
\hline Berkeley, Miles Joseph & Berk. & Great Britain & 5300 & 1803-1889 \\
\hline Spegazzini, Carlo Luigi & Speg. & Italy/Argentina & 4900 & $1858-1926$ \\
\hline Nylander, William & Nyl. & Finland/France & 3720 & $1822-1899$ \\
\hline Ellis, Job Bicknell & Ellis & U.S.A. & 3521 & 1829-1905 \\
\hline Sydow, Hans & Syd. & Germany & 3451 & 1879-1946 \\
\hline Hennings, Paul Christoph & Henn. & Germany & 3429 & 1841-1908 \\
\hline Fries, Elias Magnus & Fr. & Sweden & 3210 & 1794-1878 \\
\hline Cooke, Mordecai Cubitt & Cooke & Great Britain & 2955 & $1825-1914$ \\
\hline Velenovský, Josef & Velen. & Czech Republic & 2700 & $1858-1949$ \\
\hline Peck, Charles Horton & Peck & U.S.A. & 2493 & $1833-1917$ \\
\hline Sydow, Paul & P. Syd. & Germany & 2331 & $1851-1925$ \\
\hline Müller Argoviensis, Johannes & Müll. Arg. & Switzerland & 2309 & $1828-1896$ \\
\hline Persoon, Christiaan Hendrik & Pers. & Sweden & 2269 & $1761-1836$ \\
\hline Singer, Rolf & Singer & Germany/U.S.A. & 2260 & 1906-1994 \\
\hline Everhart, Benjamin Matlack & Everh. & U.S.A. & 2225 & 1818-1904 \\
\hline Crous, Pedro Willem & Crous & Netherlands & 2027 & $1963-$ \\
\hline Petrak, Franz & Petr. & Austria/Czech Republic & 1941 & $1886-1973$ \\
\hline Murrill, William Alphonso & Murrill & U.S.A. & 1930 & $1869-1957$ \\
\hline Vainio, Edvard August & Vain. & Finland & 1923 & $1853-1929$ \\
\hline Patouillard, Narcisse Theophile & Pat. & France & 1833 & $1854-1926$ \\
\hline Hyde, Kevin D. & K.D. Hyde & Great Britain/Thailand & 1820 & $1955-$ \\
\hline Rehm, Heinrich & Rehm & Germany & 1738 & $1828-1916$ \\
\hline Curtis, Moses Ashley & M.A. Curtis & U.S.A. & 1726 & $1808-1872$ \\
\hline Zahlbruckner, Alexander & Zahlbr. & Austria & 1698 & $1860-1938$ \\
\hline Batista, Augusto Chaves & Bat. & Brazil & 1688 & 1916-1967 \\
\hline Schweinitz, Lewis David von & Schwein. & Germany/U.S.A. & 1646 & $1780-1834$ \\
\hline Smith, Alexander Hanchett & A.H. Sm. & U.S.A. & 1578 & 1904-1986 \\
\hline Karsten, Petter Adolf & P. Karst. & Finland & 1566 & $1834-1917$ \\
\hline Broome, Christopher Edmund & Broome & Great Britain & 1443 & $1812-1886$ \\
\hline Thaxter, Roland & Thaxt. & U.S.A. & 1436 & $1858-1932$ \\
\hline Montagne, Jean Pierre Francois Camille & Mont. & France & 1391 & $1784-1866$ \\
\hline Hansford, Clifford Gerald & Hansf. & Great Britain & 1285 & 1900-1966 \\
\hline Massee, George Edward & Massee & Great Britain & 1267 & $1850-1917$ \\
\hline Corner, Edred John Henry & Corner & Great Britain/Singapore & 1183 & 1906-1997 \\
\hline Lloyd, Curtis Gates & Lloyd & U.S.A. & 1159 & $1859-1926$ \\
\hline Elix, John Alan & Elix & Australia & 1147 & $1941-$ \\
\hline Fuckel, Karl Wilhelm Gottlieb Leopold & Fuckel & Germany & 1126 & $1821-1876$ \\
\hline Bresàdola, Giacopo & Bres. & Italy & 1115 & $1847-1929$ \\
\hline Ciferri, Raffaele & Cif. & Italy & 1085 & 1897-1964 \\
\hline Sawada, Kaneyoshi & Sawada & Japan & 1076 & $1888-1950$ \\
\hline Horak, Egon & E. Horak & Austria & 1016 & $1937-$ \\
\hline Lücking, Robert & Lücking & Germany & 1000 & $1964-$ \\
\hline Braun, Uwe & U. Braun & Germany & 975 & $1953-$ \\
\hline Magnusson, Hugo & H. Magn. & Sweden & 956 & $1885-1964$ \\
\hline Acharius, Erik & Ach. & Sweden & 877 & $1757-1819$ \\
\hline Bubák, Frantisek & Bubák & Czech Republic & 862 & $1865-1925$ \\
\hline Rick, Johannes & Rick & Austria/Brazil & 850 & $1869-1946$ \\
\hline Hosagoudar, Virupakshagouda Bhimanagouda & Hosag. & India & 839 & $1953-$ \\
\hline Passerini, Giovanni & Pass. & Italy & 839 & $1816-1893$ \\
\hline Höhnel, Franz Xaver Rudolf von & Höhn. & Austria & 800 & $1852-1920$ \\
\hline
\end{tabular}


TABLE 1. (Continued)

\begin{tabular}{|c|c|c|c|c|}
\hline Name & Abbreviation & Country & Specie & Lifetime \\
\hline Léveillé, Joseph-Henri & Lév. & France & 796 & $1796-1870$ \\
\hline Aptroot, André & Aptroot & Netherlands & 775 & $1961-$ \\
\hline Dodge, Carroll William & C.W. Dodge & U.S.A. & 762 & $1895-1988$ \\
\hline Schumacher, Heinrich Christian Friedrich & Schumach. & Denmark & 729 & $1757-1830$ \\
\hline Thümen, Felix von & Thüm. & Germany & 718 & 1839-1892 \\
\hline Corda, August Karl Joseph & Corda & Czech Republic & 715 & $1809-1872$ \\
\hline Petch, Thomas & Petch & Great Britain & 702 & $1870-1948$ \\
\hline Henry, Robert & Rob. Henry & France & 697 & 1906-2001 \\
\hline Stevens, Frank Lincoln & F. Stevens & U.S.A. & 689 & $1871-1934$ \\
\hline Matsushima, Takashi & Matsush. & Japan & 682 & [no data] \\
\hline Britzelmayr, Max & Britzelm. & Germany & 674 & 1839-1909 \\
\hline Bouly de Lesdain, Maurice & B. de Lesd. & France & 631 & $1869-1965$ \\
\hline González Fragoso, Romualdo & Gonz. Frag. & Spain & 629 & $1862-1928$ \\
\hline Arthur, Joseph Charles & Arthur & U.S.A. & 610 & $1850-1942$ \\
\hline Oudemans, Cornelius Anton Jan Abraham & Oudem. & Netherlands & 605 & $1825-1906$ \\
\hline Dearness, John & Dearn. & Canada & 583 & $1852-1954$ \\
\hline Dietel, Paul & Dietel & Germany & 580 & $1860-1947$ \\
\hline Stirton, James & Stirt. & Great Britain & 552 & 1833-1917 \\
\hline Quélet, Lucien & Quél. & France & 537 & $1832-1899$ \\
\hline Hale, Mason Ellsworth & Hale & U.S.A. & 536 & $1928-1990$ \\
\hline Hesler, Lexemuel Ray & Hesler & U.S.A. & 533 & $1888-1977$ \\
\hline Wallroth, Carl Friedrich Wilhelm & Wallr. & Germany & 533 & $1792-1857$ \\
\hline Motyka, Józef & Motyka & Poland & 532 & $1900-1984$ \\
\hline Moser, Meinhard & M.M. Moser & Austria & 528 & 1924-2002 \\
\hline Bulliard, Jean Baptiste Francois & Bull. & France & 521 & $1752-1793$ \\
\hline Ryvarden, Leif & Ryvarden & Norway & 520 & $1935-$ \\
\hline Fée, Antoine Laurent Apollinaire & Fée & France & 509 & $1789-1874$ \\
\hline Romagnesi, Henri Charles Louis & Romagn. & France & 500 & 1912-1999 \\
\hline Holway, Edward Willet Dorland & Holw. & U.S.A. & 499 & $1853-1923$ \\
\hline Desmazières, John Baptiste Henri Joseph & Desm. & France & 493 & $1786-1862$ \\
\hline Wingfield, Michael John & M.J. Wingf. & South Africa & 489 & $1954-$ \\
\hline Link, Johann Heinrich Friedrich & Link & Germany & 488 & $1767-1851$ \\
\hline Candolle, Augustin Pyramus de & DC. & Switzerland & 486 & $1778-1841$ \\
\hline Massalongo, Abramo Bartolommeo & A. Massal. & Italy & 484 & $1824-1860$ \\
\hline Cummins, George Baker & Cummins & U.S.A. & 481 & 1904-2007 \\
\hline Reumaux, Patrick & Reumaux & France & 470 & $1942-$ \\
\hline Ahmad, Sultan & S. Ahmad & Pakistan & 468 & $1910-1983$ \\
\hline Castañeda, Rafael F. & R.F. Castañeda & Cuba & 468 & $1951-$ \\
\hline Kalchbrenner, Karoly & Kalchbr. & Austria/Hungary & 465 & $1807-1886$ \\
\hline Hollós, Ladislaus & Hollós & Hungary & 455 & $1859-1940$ \\
\hline Penzig, Albert Julius Otto & Penz. & Germany & 446 & $1856-1929$ \\
\hline Tassi, Flaminio & Tassi & Italy & 445 & $1851-1917$ \\
\hline Sousa da Câmara, Manuel Emmanuele de & Sousa da Câmara & Portugal & 444 & $1871-1955$ \\
\hline Vánky, Kálmán & Vánky & Sweden/Hungary & 439 & $1930-$ \\
\hline Hue, Auguste-Marie & Hue & France & 436 & $1840-1917$ \\
\hline Allescher, Andreas & Allesch. & Germany & 432 & $1828-1903$ \\
\hline Harkness, Harvey Wilson & Harkn. & U.S.A. & 430 & $1821-1901$ \\
\hline Servít, Miroslav & Servít & Czech Republic & 427 & $1886-1959$ \\
\hline Tuckerman, Edward & Tuck. & U.S.A. & 424 & $1817-1886$ \\
\hline Sutton, Brian Charles & B. Sutton & Great Britain & 420 & $1938-$ \\
\hline Batsch, August Johann Georg Karl & Batsch & Germany & 418 & $1761-1802$ \\
\hline
\end{tabular}


TABLE 1. (Continued)

\begin{tabular}{|c|c|c|c|c|}
\hline Name & Abbreviation & Country & Specie & Lifetime \\
\hline Samuels, Gary Joseph & Samuels & U.S.A. & 418 & $1944-$ \\
\hline Kirschstein, Wilhelm & Kirschst. & Germany & 417 & $1863-1946$ \\
\hline Thirumalachar, Mandayani Jeersannidhi & Thirum. & India & 414 & 1914-1999 \\
\hline Sowerby, James & Sowerby & Great Britain & 412 & $1757-1822$ \\
\hline Krempelhuber, August von & Kremp. & Germany & 410 & $1813-1882$ \\
\hline Vězda, Antonín & Vězda & Czech Republic & 409 & 1920-2008 \\
\hline Maire, Rene Charles Joseph Ernest & Maire & France & 408 & $1878-1949$ \\
\hline Roumeguère, Casimir & Roum. & France & 407 & $1828-1892$ \\
\hline Doidge, Ethel Mary & Doidge & Great Britain/South Africa & 403 & $1887-1965$ \\
\hline Rostrup, Emil & Rostr. & Denmark & 397 & $1831-1907$ \\
\hline Rabenhorst, Gottlob Ludwig & Rabenh. & Germany & 395 & $1806-1881$ \\
\hline Noordeloos, Machiel Evert & Noordel. & Netherlands & 387 & $1949-$ \\
\hline Winter, Heinrich Georg & G. Winter & Germany & 372 & $1848-1887$ \\
\hline Cesati, Vincenzo de & Ces. & Italy & 370 & $1806-1883$ \\
\hline Schulzer von Müggenburg, Stephan V.M. & Schulzer & Hungary/Croatia & 370 & $1803-1892$ \\
\hline Kalb, Klaus & Kalb & Germany & 369 & $1942-$ \\
\hline Gilles, Gérard & Gilles & France & 366 & $1921-2005$ \\
\hline Räsänen, Veli Johannes Paavo Bartholomeus & Räsänen & Finland & 366 & $1888-1953$ \\
\hline Samson, Robert Archibald & Samson & Netherlands & 352 & $1946-$ \\
\hline Fautrey, Francois & Fautrey & France & 350 & $1833-1905$ \\
\hline Preuss, Carl Gottlieb Traugott & Preuss & Germany & 350 & $1795-1855$ \\
\hline Bonorden, Hermann Friedrich & Bonord. & Germany & 346 & $1801-1884$ \\
\hline Etayo Salazar, Javier & Etayo & Spain & 346 & $1959-$ \\
\hline Beeli, Maurice & Beeli & Belgium & 342 & 1879-1957 \\
\hline Dennis, Richard William George & Dennis & Great Britain & 340 & 1910-2003 \\
\hline Gyelnik, Vilmos Kofarago & Gyeln. & Hungary & 338 & $1906-1945$ \\
\hline Kamal & Kamal & India & 332 & [no data] \\
\hline Kühner, Robert & Kühner & France & 332 & 1904-1997 \\
\hline McAlpine, Daniel & McAlpine & Great Britain/Australia & 332 & $1849-1932$ \\
\hline Guarro, Josep & Guarro & Spain & 331 & $1948-$ \\
\hline Brunaud, Paul & Brunaud & France & 330 & $18 ? ?-1903$ \\
\hline Bidaud, André & Bidaud & France & 322 & $1949-$ \\
\hline Kobayasi, Yoshio & Kobayasi & Japan & 321 & $1907-1993$ \\
\hline Jackson, Herbert Spencer & H.S. Jacks. & U.S.A. & 319 & $1883-1951$ \\
\hline Sipman, Henricus Johannes Maria [Harrie] & Sipman & Netherlands/Germany & 317 & $1945-$ \\
\hline Archer, Alan W. & A.W. Archer & Australia & 313 & $1930-$ \\
\hline Hariot, Paul Auguste & Har. & France & 312 & 1854-1917 \\
\hline Kondratyuk, Sergey Ya. & S.Y. Kondr. & Ukraine & 310 & $1959-$ \\
\hline Diederich, Paul & Diederich & Luxembourg & 307 & $1959-$ \\
\hline Boudier, Jean Louis Emile & Boud. & France & 306 & $1828-1920$ \\
\hline Deighton, Frederick Claude & Deighton & Great Britain & 304 & 1903-1992 \\
\hline Cunningham, Gordon Herriott & G. Cunn. & New Zealand & 303 & $1892-1962$ \\
\hline Earle, Franklin Sumner & Earle & U.S.A. & 303 & $1856-1929$ \\
\hline Scopoli, Joannes Antonius & Scop. & Italy/Austria & 300 & $1723-1788$ \\
\hline De Notaris, Giuseppe De & De Not. & Italy & 298 & $1805-1877$ \\
\hline Körber, Gustav Wilhelm & Körb. & Germany & 297 & $1817-1885$ \\
\hline Poelt, Josef & Poelt & Austria & 296 & 1924-1995 \\
\hline Berlese, Augusto Napoleone & Berl. & Italy & 292 & $1864-1903$ \\
\hline Hoffmann, George Franz & Hoffm. & Germany & 292 & $1761-1826$ \\
\hline Malme, Gustaf Oskar Andersson & Malme & Sweden & 292 & 1864-1937 \\
\hline Westendorp, Gerard Daniel & Westend. & Netherlands/Belgium & 284 & $1813-1869$ \\
\hline
\end{tabular}


TABLE 1. (Continued)

\begin{tabular}{|c|c|c|c|c|}
\hline Name & Abbreviation & Country & Specie & Lifetime \\
\hline Heim, Roger & R. Heim & France & 283 & 1900-1979 \\
\hline Burt, Edward Angus & Burt & U.S.A. & 282 & 1859-1939 \\
\hline Gucevič, S.A. & Gucevič & Ukraine/Russia & 282 & [no data] \\
\hline Müller, Emil & E. Müll. & Switzerland & 282 & 1920-2008 \\
\hline Schaeffer, Jacob Christian & Schaeff. & Germany & 279 & $1718-1790$ \\
\hline Schröter, Joseph & J. Schröt. & Germany & 276 & $1837-1894$ \\
\hline Heinemann, Paul & Heinem. & Belgium & 275 & 1916-1996 \\
\hline Lasch, Wilhelm Gottfried & Lasch & Germany/Poland & 275 & $1787-1863$ \\
\hline Atkinson, George Francis & G.F. Atk. & U.S.A. & 274 & 1854-1918 \\
\hline Phillips, William & W. Phillips & Great Britain & 269 & $1822-1905$ \\
\hline Pilát, Albert & Pilát & Czech Republic & 269 & $1903-1974$ \\
\hline Yen, Jo-Min & J.M. Yen & France/U.S.A. & 268 & $1908-$ \\
\hline Udagawa, Shun-ichi & Udagawa & Japan & 267 & $1931-$ \\
\hline Shivas, Roger G. & R.G. Shivas & Australia & 266 & [no data] \\
\hline Svrček, Mirko & Svrček & Czech Republic & 266 & $1925-2017$ \\
\hline Gams, Walter & W. Gams & Austria & 265 & $1934-2017$ \\
\hline Patwardhan, Parashuram Gangadhar & Patw. & India & 263 & $1935-$ \\
\hline Boidin, Jacques & Boidin & France & 262 & $1822-2013$ \\
\hline Durieu de Maisonneuve, Michel Charles & Durieu & France & 261 & $1796-1878$ \\
\hline Petersen, Ronald H. & R.H. Petersen & U.S.A. & 261 & $1934-$ \\
\hline Feltgen, Johann & Feltgen & Germany & 260 & 1833-1904 \\
\hline Zhuang, Wen Ying & W.Y. Zhuang & China & 259 & $1948-$ \\
\hline Dai, Yu Cheng & Y.C. Dai & China & 258 & $1964-$ \\
\hline Kendrick, William Bryce & W.B. Kendr. & Great Britain & 257 & $1933-$ \\
\hline Rao, Vasant Gurunath & V.G. Rao & India & 257 & $1937-$ \\
\hline Zhang, Tian Yu & T.Y. Zhang & China & 257 & $1937-$ \\
\hline Katumoto, Ken & Katum. & Japan & 256 & $1927-$ \\
\hline Drechsler, Charles & Drechsler & U.S.A. & 254 & 1892-1986 \\
\hline Buyck, Bart & Buyck & France & 253 & $1959-$ \\
\hline Ellis, Martin Beazor & M.B. Ellis & Great Britain & 253 & $1911-1996$ \\
\hline Chupp, Charles David & Chupp & U.S.A. & 252 & $1886-1967$ \\
\hline Knight, Charles & C. Knight & Great Britain/Australia & 250 & $1818-1895$ \\
\hline Cáceres, Marcela E.S. & M. Cáceres & Brazil & 249 & $1971-$ \\
\hline Makhija, Urmila V. & Makhija & India & 249 & $1950-$ \\
\hline Taylor, Thomas & Taylor & Great Britain & 248 & $1775-1848$ \\
\hline Cleland, John Burton & Cleland & Australia & 247 & $1878-1971$ \\
\hline Hawksworth, David Leslie & D. Hawksw. & Great Britain & 247 & $1946-$ \\
\hline Nakase, Takashi & Nakase & Japan & 247 & 1939-2018 \\
\hline Bezerra, Jose Luiz & J.L. Bezerra & Brazil & 246 & [no data] \\
\hline Desjardin, Dennis E. & Desjardin & U.S.A. & 245 & $1950-$ \\
\hline Pegler, David Norman & Pegler & Great Britain & 245 & $1938-$ \\
\hline Raciborski, Marjan & Racib. & Poland & 244 & $1863-1917$ \\
\hline Camporesi, Erio & Camporesi & Italy & 242 & [no data] \\
\hline Jørgensen, Per Magnus & P.M. Jørg. & Norway & 241 & 1944 \\
\hline Hara, Kanesuke & Hara & Japan & 240 & $1885-1962$ \\
\hline Starbäck, Karl & Starbäck & Sweden & 240 & $1863-1931$ \\
\hline Raitviir, Ain & Raitv. & Estonia & 239 & 1938-2006 \\
\hline
\end{tabular}




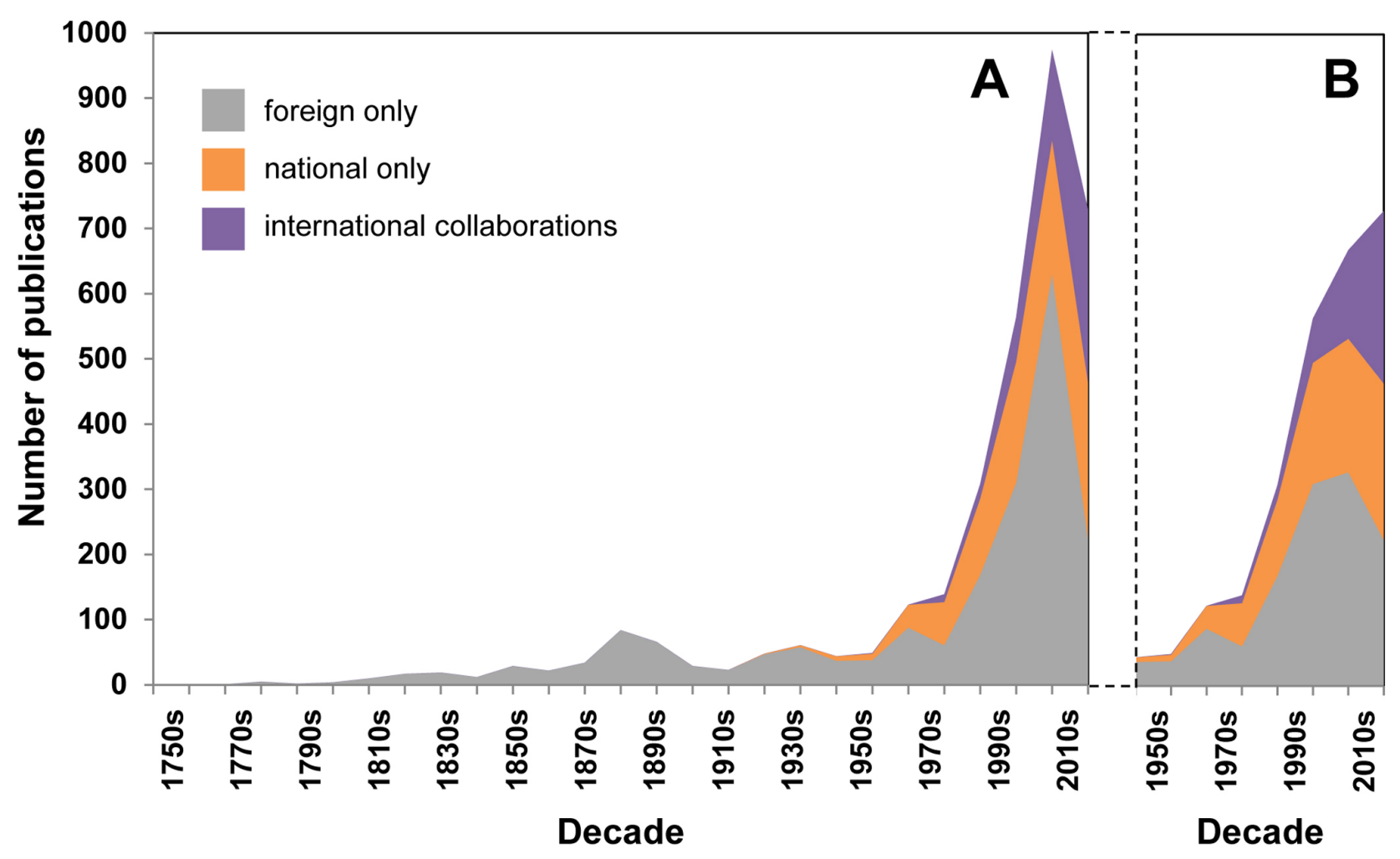

FIGURE 4. Publications on lichens in Latin America from the 1750s to the present, showing trends in overall production and the relation between exclusively foreign or national and collaborative studies (see Supplementary file for detailed data). The peak during the 2000s (A) is largely due to the 305 individual contributions of authors to the Mexican portion of the Lichen Flora of the Greater Sonoran Desert Region (Nash et al. 2002, 2004, 2007), 303 of which were exclusively authored by foreign taxonomists. Removing these adjusts the proportions (B).

when molecular techniques began to emerge, and since the 1960s almost all taxonomic studies in lichens routinely employ chemotaxonomy. As a result, taxonomic works on lichens employing molecular and/or chemotaxonomic methods outnumber natural product screening studies by more than an order of magnitude, but almost all of it falls under the Nagoya Protocol. This similarly applies to other organisms. Therefore, the bulk of the bureaucratic burden associated with the protocol, both for researchers and for the administrators checking these data, lies in fields of basic research that are not part of the problem actually targeted by these regulations. It has also been argued that the protocol, while putting additional burdens on noncommercial biodiversity research, does not effectively prevent biopiracy (Rabitz 2015). Further, the measure comes at a time when the pharmaceutical industry has largely shifted to synthetic, combinatorial chemistry (Beutler 2009), and results in terms of drugs derived from broad-scale biodiversity screening programs are very limited (Snader \& McCloud 1994). Therefore, the need of implementing such a complex instrument, affecting all areas of biodiversity research, at this point is questionable.
If indeed a renaissance of natural product research is envisioned (Wildman 2003; Beutler 2009), the protocol and its implementation could have been made much more target-oriented.

That basic research per se is not intentionally targeted by the Nagoya Protocol is shown by the fact that the protocol only applies to research employing molecular methods and/or biochemistry ("genetic resources"), or related traditional knowledge (ethnotaxonomy). Studies not incorporating these aspects, such as phenotype-based taxonomy, are not regulated in this context, even if they may have the same objectives. Sadly, the interpretation of the term "genetic resources" by policy makers suffers from a misguided idea that genes or secondary chemical compounds by default equal utilization in terms of potential revenue. Taxonomy and systematics and their associated fields rely on genetic markers that are universal across the Tree of Life and code for basic cell functions present in all organisms. These markers play no taxon-specific role in the biochemical makeup that would be of interest for e.g. natural product screening. Sequences produced for taxonomic and systematic purposes thus have no 
commercial value and the idea of such data to provide a national resource for revenue exploitation is nonsense. The currently discussed idea that published basic digital sequence information (DSI) should be regulated under the Nagoya Protocol is not just misguided (Kupferschmidt 2018; Laird \& Wynberg 2018), but contradicts established ethics of scientific conduct, according to which published data, including sequence data, must be broadly and freely accessible (Arzberger et al. 2004; Mauthner et al. 2013; Amann et al. 2019). While it is obvious that commercial, revenue-producing use of DSI must fall under the protocol, there is no known benefit-sharing mechanism for the repeated use of once published sequence data for basic research, other than properly citing the source. Offering repeated coauthorship to the generator(s) of the same, already published data would be against scientific ethics (Shewan \& Coats 2010; Texeira da Silva \& Dobránszki, J. (2016) and would be like paying multiple tax on the same item.

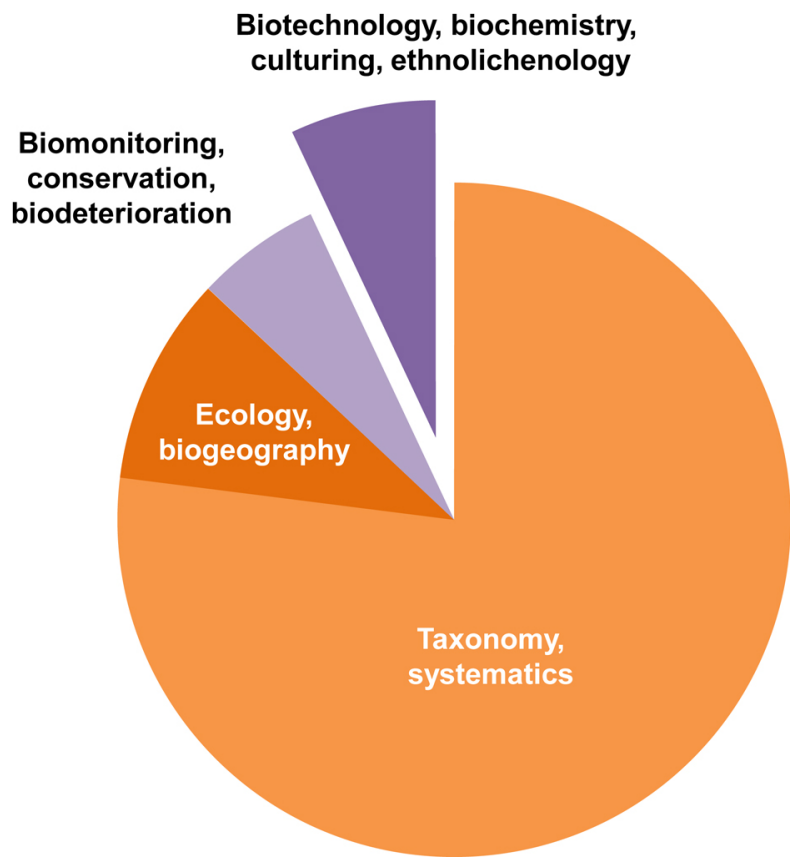

FIGURE 5. Proportional distribution of major topics among 3,403 publications on Latin American lichens from 1750 to present (analysed from the Recent Literature on Lichens database, RLL: http://nhm2.uio.no/botanisk/lav/RLL/RLL. HTM). Only $7 \%$ of these are dealing with potential revenue generation; yet, most of the other $93 \%$ are burdened with the same obligations regarding the Nagoya Protocol, as long as they include molecular phylogenetic or chemotaxonomic approaches.

Taxonomy is self-regulating in terms of benefitsharing. In a non-commercial context of basic research, benefit-sharing cannot be monetary. The Consortium of European Taxonomic Facilities (CETAF) has provided the CETAF Code of Conduct and Best Practice for Access and Benefit-Sharing [https://www.cbd.int/abs/ submissions/icnp-3/EU-Taxonomic-practices.pdf], where it specifies non-monetary benefits such as capacitation and joint publications, based on the annex of the Nagoya Protocol. A further aspect is the deposition of reference collections in national herbaria (Smith \& Figueiredo 2011). There are thus three important components of nonmonetary benefit-sharing for taxonomic research: joint publications, capacitation, and reference collections, in particularly type material, in the country of origin (Smith \& Figueiredo 2011; Habel et al. 2014).

The field of taxonomy is essentially self-regulating when it comes to benefit-sharing, although it has been a steep learning curve (Smith \& Figueiredo 2011). As outlined above, until about the 1920s, lichenology in Latin America was exclusively performed by researchers in Europe and North America, with no joint publications or evidence of regional and local capacitation (Fig. 3, 4). At best, few reference collections were deposited in national herbaria, such as Malme's Lichenes Austroamericani ex Herbario Regnelliano in the Museu Nacional in Rio de Janeiro (R), but almost all type material from this period is housed in European and North American institutions. Regional expertise in Latin American lichenology began to develop chiefly after World War II, particularly in Brazil and Argentina (Rizzini 1947, 1952; Grassi 1950; Mors 1952; Batista 1961), whereas collaborative research with joint publications started only in the 1970s (XavierFilho \& Kurokawa 1971) and strongly increased since the 1990s. During the past decade, lichenology in Latin America has been well-balanced between external (31\%), internal (33\%) and collaborative (36\%) contributions (Fig. 4). These developments initiated before the CBD and long before the Nagoya Protocol and are mirrored in research on other organism groups, although a dominance of European and North American institutions can still be observed (Habel et al. 2014).

One outstanding example of non-commercial benefit-sharing in taxonomic research is Brazil, which currently has one of the strictest implementations of the Nagoya Protocol in Latin America, although the protocol itself has not yet been ratified in the country (Smith et al. 2017; Silva 2019). Since 1979, Brazil has produced over 30 lichenologists with a $\mathrm{PhD}$ degree, a number well above that of any other biodiversity-rich country, and many with permanent positions. More than one third of these, representing three generations, go back to the extremely fruitful collaboration between the German lichenologist Klaus Kalb, who spent three years in Brazil between 1978 and 1981, and Brazilian lichenologist Marcelo Pinto Marcelli. During this period, Marcelli received three years of intensive training by Kalb and later on assistance for the completion of his PhD thesis in 1987. In a recent paper, Marcelli commented to his mentor on this period: "I remember clearly how you, immediately, offered your expertise and advice, opening your house's 
doors, books, and equipment to a completely unknown person. I remember how, for about three years, you spent a half-day ... patiently teaching me. I cannot forget our conversations and discussions about books, authors, taxonomy, etc. or the wonderful field trips, all paid by you. I cannot also forget the sense of ethics, commitment, and social responsibility I learnt from you. Do you remember when I asked you the reason for such a big investment in me, and you replied: I feel I owe this to Brazil? Moreover, when you supported me because my grant failed to be paid: You will pay me by doing the same for a student of yours in the future." (Marcelli et al. 2007: 2010). Between 2006 and 2015, Marcelli formed nine PhD students, one of which, Suzana Martins, has trained two further $\mathrm{PhD}$ students between 2011 and 2016. This has essentially laid the foundation for modern lichenology in Brazil.

The remarkable development of lichenology in Colombia is largely due to the work of Harrie Sipman, who first trained Jaime Aguirre-Ceballos (Sipman \& Aguirre-C. 1982), who in turn formally mentored Bibiana Moncada's doctoral thesis (Moncada 2012; Moncada et al. 2014). The latter has since broadly promoted lichenology in the country through the Grupo Colombiano de Liquenología (GCOL; http://licbiologia.udistrital.edu. co:8080/grupo-colombiano-de-liquenologia), with a large number of thesis works at the undergraduate, master, and even doctoral level at various universities completed and in part published (Ardila-Ríos et al. 2015; Díaz-Escandón et al. 2015; Ramírez-Morán et al. 2016; Simijaca et al. 2018; Motta et al. 2019). Similar examples of benefitsharing for capacity building could be given for other lichenologists in Brazil (Cáceres et al. 2007; Cáceres \& Aptroot 2016; Kirika et al. 2017; Menezes et al. 2018), Mexico (Herrera-Campos et al. 1998), Costa Rica (Umaña \& Sipman 2002; Chaves et al. 2004), Peru (Rivas Plata \& Lumbsch 2011), Bolivia (Flakus \& Printzen 2014), Kenya (Kirika et al. 2017, 2019), Sri Lanka (Weerakoon et al. 2012, 2016), Thailand (Boonpragob et al. 1998; Homchantara \& Coppins 2002; Papong et al. 2009; Kraichak et al. 2015), among many others. Indeed, foreign experts in tropical lichenology, located across Europe, North America and Australia, have long and persistently engaged in the capacitation of regional expertise in tropical countries, with remarkable cascading effects. Comparable endeavors exist for mycology in general, such as the remarkable efforts by Meike Piepenbring in Panama (Piepenbring 2007) and her bilingual introductory textbook on tropical mycology (Piepenbring 2015a, b), the highly productive Center of Excellence in Fungal Research in Thailand spearheaded by Kevin Hyde, and the successful model of combining solid taxonomy with advanced natural compound chemistry by Mark Stadler's lab in the Helmhotz Zentrum für Infektionsforschung (De Silva et al. 2013; Helaly et al. 2018; Hyde et al. 2019).
The Kalb-Marcelli example is the embodiment of the spirit of the CBD and the Nagoya Protocol, set in motion more than a decade prior to the $\mathrm{CBD}$, and numerous similar stories could be told related to other instances mentioned above. It is how taxonomy and associated fields of biodiversity research have worked for many decades, without the need of "policing", the occasional black sheep notwithstanding. However, these accomplishments have been overlooked, so it is necessary to spell them out. The data on rapidly increasing collaborative publications (Fig. 4) speak for themselves, and practices on depositing type and other reference material have changed substantially (Smith \& Figueiredo 2011). There has been a strong trend to deposit holotypes (as usually required by national law) or at least isotypes in the country of origin; recent studies do this almost exclusively, except for those based on historical material still housed in foreign herbaria. In the latter case, the argument could be made to repatriate portions of the type material to a national herbarium, in the spirit of CBD Art. 17.2.

Unfortunately, strict legal requirements to deposit reference collections and particularly valuable type material in national herbaria do not always go in hand with the practical implementations of permanent specimen curation in the countries of origin. Biodiversity-rich countries often do not invest in proper storage facilities or curatorial positions to process and maintain the material. One example case is the type and other reference material originating from a study on foliicolous lichens in Ecuador, based on a formal research permit, by the very author of this paper (Lücking 1999). After shipping the material to the national herbarium in Quito (QCNE), the parcel came back months later, practically unopened, with the argument that the staff at the herbarium did not know what to do with it. Indeed, the issues leading up to the CBD and the Nagoya Protocol are two-sided: it is not only the "developed" countries that should be held responsible for fair and equitable benefit sharing; biodiversityrich countries are responsible for investing in the necessary logistics to allow implementing existing legislation, including well-equipped and well-curated biodiversity repositories as well as a sound scientific infrastructure, to allow successful collaborations in the first place. Regarding metrics such as area, population size, and especially plant species richness, biodiversityrich countries are notoriously underequipped when it comes to herbaria (Table 2).

Some biodiversity-rich countries such as Colombia have realized that implementation of the Nagoya Protocol for basic studies in taxonomy and systematics and related fields will hinder progress in these areas. In Colombia, the Decreto 1376 de 2013 [http://www.minambiente.gov. co/images/normativa/decretos/2013/dec_1376_2013.pdf] states in paragraph 5: "Las investigaciones cientificas 
TABLE 2. Examples of the number of herbaria for two countries in Europe and North America with a history of prolific species descriptions based on tropical material, and for two of the most biodiversity-rich countries on Earth. Numbers of herbaria are based on Index Herbariorum [http://sweetgum.nybg.org/science/ih] and are compared to area and population size and the number of recorded plant species.

\begin{tabular}{lrccrrrr}
\hline Country & Herbaria & $\begin{array}{c}\text { Area } \\
{\left[\mathbf{k m}^{\mathbf{2}}\right]}\end{array}$ & Population & $\begin{array}{c}\text { Plant } \\
\text { species }\end{array}$ & $\begin{array}{c}\text { Herbaria per } \\
\mathbf{1 0 , 0 0 0} \mathbf{~ k m}^{\mathbf{2}}\end{array}$ & $\begin{array}{c}\text { Herbaria per } \\
\text { Mio. people }\end{array}$ & $\begin{array}{c}\text { Herbaria per } \\
\mathbf{1 , 0 0 0} \text { plant species }\end{array}$ \\
\hline Germany & 80 & 357,000 & 83 Mio. & 4,100 & 2,24 & 0,96 & 19,51 \\
United States & 836 & $9,800,000$ & 327 Mio. & 19,500 & 0,85 & 2,56 & 42,87 \\
Colombia & 37 & $1,140,000$ & 49 Mio. & 51,000 & 0,32 & 0,76 & 0,73 \\
Brazil & 202 & $8,500,000$ & 209 Mio. & 56,000 & 0,24 & 0,97 & 3,61 \\
\hline
\end{tabular}

básicas que se adelantan en el marco de un permiso de recolección de especímenes de especies silvestres de la diversidad biológica con fines no comerciales y que involucren actividades de sistemática molecular, ecología molecular, evolución y biogeografía, no configuran acceso al recurso genético de conformidad con el ámbito de aplicación del presente decreto." [Basic scientific research carried out within the framework of a permit to collect specimens of wild species of biological diversity for non-commercial purposes and which involves activities of molecular systematics, molecular ecology, evolution and biogeography, does not configure access to the genetic resource in compliance within the scope of this decree.] Notably, this is in stark contrast with the difficulties even Colombian researchers had to perform molecular-based studies until up to the recent past (Andrade-C. 2012; González Medina 2016).

Conclusions. The CBD and the Nagoya Protocol both state that while benefit-sharing from access to genetic resources and associated traditional knowledge should be fair and regulated, basic biodiversity research should be simultaneously facilitated and simplified. Currently, this is not the case, but hopefully we get there. Fortunately, the strong development of taxonomic expertise in biodiverse countries in the past decades helps to advocate for more practical solutions. However, one cannot stop thinking that the overall global costs of implementing the Nagoya Protocol are in no relation to the intended effects regarding the prevention of biopiracy and similar problems.

The above examples show that the field of taxonomy does not require external policing to evolve self-conscience. While there are the occasional black sheep that continue to do taxonomy in foreign countries in the spirit of our forefathers from the 18th and 19th century, an instrument such as the Nagoya Protocol to educate these is like cracking a nut with a sledgehammer. Having said that: foreign taxonomists, professionals and amateurs alike, who are not already working in the spirit of collaborative research, benefit-sharing and respecting national legislation: please do so! Benefit-sharing in non-applied basic research is not only important but will make cataloging biodiversity much more effective. Also, any research should follow national legislation. However, this has overall been rather well implemented in the past decades in taxonomy and systematics, and the implementation of the CBD and the Nagoya Protocol should focus on regulating revenue-generating applied science that leads to potentially marketable products. If indeed deemed necessary, formal implementation of the Nagoya Protocol for basic biodiversity research should render the necessary processes as effective and unbureaucratic as possible, also to avoid that taxonomists based in biodiversity-rich countries have to spend their already sparse time on these cumbersome administrative issues. Colombia has set an excellent precedence how this could be resolved, and hopefully other countries will adopt this practice.

\section{Funding}

National Science Foundation DEB-0206125 and DEB0715660 .

\section{Acknowledgements}

The author is indepted to Bibiana Moncada and Astrid de Mestier for providing or helping to find specific information. The analysis on fungal authors is based on a download of Index Fungorum data from 2018 kindly provided by Paul Kirk. Part of the data used for this paper were obtained during two NSF-funded projects: TICOLICHEN-The Costa Rican Biodiversity Inventory (NSF DEB-0206125 to The Field Museum) and Neotropical Epiphytic Microlichens (NSF DEB-0715660 to The Field Museum). Shaun Pennycook provided useful remarks on an earlier version of the manuscript. 


\section{References}

Abarenkov, K., Henrik Nilsson, R., Larsson, K.H., Alexander, I.J., Eberhardt, U., Erland, S., Høiland, K., Kjøller, R., Larsson, E., Pennanen, T. \& Sen, R. (2010) The UNITE database for molecular identification of fungi-recent updates and future perspectives. New Phytologist, 186 (2), 281-285. https://doi.org/10.1111/j.1469-8137.2009.03160.x

Agnarsson, I. \& Kuntner, M. (2007) Taxonomy in a changing world: seeking solutions for a science in crisis. Systematic Biology, 56 (3), 531-539.

https://doi.org/10.1080/10635150701424546

Aldhous, P. (1991) 'Hunting licence' for drugs. Nature, 353, 290. https://doi.org/10.1038/353290a0

Alho, C.J.R. (2008) The value of biodiversity. Brazilian Journal of Biology, 68 (4), 1115-1118. http://dx.doi.org/10.1590/S1519-69842008000500018

Álvarez-León, R., Avendaño-Remolina, D. \& Sanjuan-Muñoz, A.M. (2014) The relationship between Peltigera sp. and Rhizophora mangle in Arroyo de Plata (bolivar), Colombian Caribbean region. Luna Azul, 38, 105-121.

Alves, L.F. \& Pontes, T.V.C. (2017) Research with chemistry and pharmacology of natural products in Brazil: a comparison with 70 selected countries from 5 continents. Revista Virtual de Quimica, 9 (4), 1394-1433.

https://doi.org/10.21577/1984-6835.20170082

Amann, R. I., Baichoo, S., Blencowe, B.J., Bork, P., Borodovsky, M., Brooksbank, C., Chain, P.S., Colwell, R.R., Daffonchio, D.G., Danchin, A. \& De Lorenzo, V. (2019) Toward unrestricted use of public genomic data. Science, 363 (6425), 350-352. https://doi.org/10.1126/science.aaw1280

Aoki, K. (2017) Neocolonialism, anticommons property, and biopiracy in the (not-so-brave) new world order of international intellectual property protection. In: George, A. (Ed.), Globalization and Intellectual Property. Taylor \& Francis, Routledge, pp. 195-242.

Aptroot A. \& Schumm, F. (2011) Fruticose Roccellaceae: An Anatomical-Microscopical Atlas and Guide with a Worldwide Key and Further Notes on some Crustose Roccellaceae or Similar Lichens. Books on Demand, Norderstedt, 370 pp.

Aptroot, A., Umaña, L., Chaves, J.L. \& Trest, M.T. (2006) A first assessment of the TICOLICHEN biodiversity inventory in Costa Rica: three new squamulose genera (Lecanorales: Ramalinaceae and Pilocarpacaeae). The Journal of the Hattori Botanical Laboratory, 100, 617-623.

https://doi.org/10.18968/jhbl.100.0_617

Aptroot, A., Lücking, R., Sipman, H. J.M., Umaña, L. \& Chaves, J.L. (2008) A first assessment of the lichen biodiversity inventory in Costa Rica: Pyrenocarpous lichens with bitunicate asci. Bibliotheca Lichenologica, 97, 1-162.

Ardila-Rios, A.I., Moncada, B. \& Lücking, R. (2015) Epiphyte homogenization and de-diversification on alien Eucalyptus versus native Quercus forest in the Colombian Andes: a case study using lirellate Graphidaceae lichens. Biodiversity and Conservation, 24, 1239-1252. https://doi.org/10.1007/s10531-014-0855-7

Arzberger, P., Schroeder, P., Beaulieu, A., Bowker, G., Casey, K., Laaksonen, L., Moorman, D., Uhlir, P. \& Wouters, P. (2004) Promoting access to public research data for scientific, economic, and social development. Data Science Journal, 3 , $135-152$.

https://doi.org/10.2481/dsj.3.135
Avendaño-Remolina, D., Sanjuan-Munoz, A. \& Álvarez-León, R. (2000) New lichen in the mangrove swamps of the Colombian Caribbean coast. Revista de Biologia Tropical, 48 (2/3), 719719.

Bank, D. (2002) All species great and small-taxonomists unite to catalog the planet's biodiversity; possible cost? $\$ 3$ billion. The Wall Street Journal, B1, 2002.

Barber, P.H., Ablan-Lagman, M.C.A., Berlinck, R.G., Cahyani, D., Crandall, E.D., Ravago-Gotanco, R., Juinio-Meñez, M. A., Mahardika, I. G., Shanker, K., Starger, C. J. \& Toha, A. H. A. (2014) Advancing biodiversity research in developing countries: the need for changing paradigms. Bulletin of Marine Science, 90 (1), 187-210.

https://doi.org/10.5343/bms.2012.1108

Barnosky, A.D., Matzke, N., Tomiya, S., Wogan, G.O., Swartz, B., Quental, T.B., Marshall, C., McGuire, J. L., Lindsey, E.L., Maguire, K.C. \& Mersey, B. (2011) Has the Earth's sixth mass extinction already arrived? Nature, 471 (7336), 51-57. https://doi.org/10.1038/nature09678

Barrow, M.V. (1998) A Passion for Birds: American Ornithology after Audubon. Princeton University Press, Princeton, NJ, 336 pp.

Bass, D. \& Richards, T.A. (2011) Three reasons to re-evaluate fungal diversity 'on Earth and in the ocean'. Fungal Biology Reviews, 25 (4), 159-164.

https://doi.org/10.1016/j.fbr.2011.10.003

Batista, A.C. (1961) Um pugilo de gêneros novos de líquens imperfeitos. Publicações, Instituto de Micologia da Universidade do Recife, 320, 1-31.

Beutler, J.A. (2019) Natural products as a foundation for drug discovery. Current Protocols in Pharmacology, 46 (1), 9.11.1-9.11.21.

https://doi.org/10.1002/0471141755.ph0911s46

Blum, E. (1993) Making biodiversity conservation profitable: a case study of the Merck/INBio agreement. Environment: Science and Policy for Sustainable Development, 35 (4), 16-45.

https://doi.org/10.1080/00139157.1993.9929092

Boonpragob, K., Homchantara, N., Coppins, B.J., McCarthy, P.M. \& Wolseley, P.A. (1998) An introduction to the lichen flora of Khao Yai National Park, Thailand. Botanical Journal of Scotland, 50, 209-219.

https://doi.org/10.1080/03746609808684918

Bortolus, A. (2008) Error cascades in the biological sciences: the unwanted consequences of using bad taxonomy in ecology. AMBIO: A Journal of the Human Environment, 37 (2), 114119.

https://doi.org/10.1579/0044-7447(2008)37[114: ECITBS]2.0.CO;2

Brodo, I.M., Sharnoff, S.D. \& Sharnoff, S. (2001) Lichens of North America. Yale University Press, New Haven, London, 828 pp.

Cáceres, M.E.S. \& Aptroot, A. (2016) First inventory of lichens from the Brazilian Amazon in Amapá State. The Bryologist 119 (3), 250-265. https://doi.org/10.1639/0007-2745-119.3.250

Cáceres, M.E.S., Lücking, R. \& Rambold, G. (2007) Phorophyte specificity and environmental parameters versus stochasticity as determinants for species composition of corticolous crustose lichen communities in the Atlantic rain forest of northeastern Brazil. Mycological Progress, 6 (3), 117-136. https://doi.org/10.1007/s11557-007-0532-2

Cannon, P.F. (1997) Diversity of the Phyllachoraceae with special reference to the tropics. In: Hyde, K.D. (Ed.), Biodiversity 
ofTropical Microfungi. Hong Kong University Press, Hong Kong, pp. 255-278.

Cantino, D.P., Bryant, H.N., Queiroz, K.D., Donoghue, M.J., Eriksson, T., Hillis, D.M., \& Lee, M.S. (1999) Species names in phylogenetic nomenclature. Systematic Biology, 48, 790807.

https://doi.org/10.1080/106351599260012

Caporale, L.H. (1996) The Merck/INBio Agreement: A Pharmaceutical Company Perspective. In: Balick, M. J., Elisabetsky, E. \& Laird, S. A. (Eds.), Medicinal Resources of the Tropical Forest: Biodiversity and Its Importance to Human Health. Columbia University Press, New York, pp.137-141.

Carvalho, M.R., Bockmann, F.A., Amorim, D.S., Brandão, C.R.F., de Vivo, M., de Figueiredo, J.L., Britski, H.A., de Pinna, M.C., Menezes, N.A., Marques, F.P., Papavero, N., Cancello, E.M., Crisci, J.V., McEachran, J.D., Schelly, R C., Lundberg, J.G., Gill, A.C., Britz, R., Wheeler, Q.D., Stiassny, M.L.J., Parenti, L.R., Page, L.M., Wheeler, W.C., Faivovich, J., Vari, R.P., Grande, L., Humphries, C.J., DeSalle, R., Ebach, M.C. \& Nelson, G.J. (2007) Taxonomic impediment or impediment to taxonomy? A commentary on systematics and the cybertaxonomic-automation paradigm. Evolutionary Biology, 34 (3-4), 140-143.

https://doi.org/10.1007/s11692-007-9011-6

Carvalho, M.R., Bockmann, F.A., Amorim, D.S. \& Brandao, C.R.F. (2008) Systematics must embrace comparative biology and evolution, not speed and automation. Evolutionary Biology, 35 (2), 150-157. https://doi.org/10.1007/s11692-008-9018-7

Caulfield, T., Harmon, S.H. \& Joly, Y. (2012) Open science versus commercialization: a modern research conflict? Genome Medicine, 4 (2), 17. https://doi.org/10.1186/gm316

Ceballos, G. \& Ehrlich, P.R. (2018) The misunderstood sixth mass extinction. Science, 360, 1080-1081. https://doi.org/10.1126/science.aau0191

Ceballos, G., Ehrlich, P.R., Barnosky, A.D., García, A., Pringle, R.M. \& Palmer, T.M. (2015) Accelerated modern humaninduced species losses: entering the sixth mass extinction. Science Advances, 1 (5), e1400253. https://doi.org/10.1126/sciadv.1400253

Ceballos, G., Ehrlich, P.R. \& Dirzo, R. (2017) Biological annihilation via the ongoing sixth mass extinction signaled by vertebrate population losses and declines. Proceedings of the National Academy of Sciences, 114 (30), E6089-E6096. https://doi.org/10.1073/pnas.1704949114

Celio, G.J., Padamsee, M., Dentinger, B.T. M., Bauer, R. \& McLaughlin, D.J. (2006) Assembling the fungal tree of life: constructing the structural and biochemical database. Mycologia, 98 (6), 850-859. https://doi.org/10.1080/15572536.2006.11832615

Chaves, J.L., Lücking, R., Sipman, H.J.M, Umaña, L. \& Navarro, E. (2004) A first assessment of the TICOLICHEN biodiversity inventory in Costa Rica: the genus Dictyonema (Polyporales: Atheliaceae). The Bryologist, 107 (2), 242-249. https://doi.org/10.1639/0007-2745(2004)107[0242: AFAOTT]2.0.CO;2

Chen, J. (2006) There's no such thing as biopiracy... and it's a good thing too. McGeorge Law Review, 37, 1-32.

Chryssavgis, J. (2015) Der grüne Patriarch Bartholomaios. Religion und Gesellschaft in Ost un West, 11, 6-7.

Clark, B.R., Godfray, H.C.J., Kitching, I.J., Mayo, S.J. \& Scoble, M.J. (2009) Taxonomy as an eScience. Philosophical
Transactions of the Royal Society A: Mathematical, Physical and Engineering Sciences, 367, 953-966.

https://doi.org/10.1098/rsta.2008.0190

Costello, M.J., Wilson, S. \& Houlding, B. (2013a) More taxonomists describing significantly fewer species per unit effort may indicate that most species have been discovered. Systematic Biology, 62 (4), 616-624.

https://doi.org/10.1093/sysbio/syt024

Costello, M.J., May, R.M. \& Stork, N.E. (2013b) Can we name Earth's species before they go extinct? Science, 339 (6118), 413-416. https://doi.org/10.1126/science.1230318

Coughlin Jr, M.D. (1993) Using the Merck-INBio agreement to clarify the Convention on Biological Diversity. Columbia Journal of Transnational Law, 31, 337-375.

Cox, D.T. \& Gaston, K.J. (2015) Likeability of garden birds: Importance of species knowledge \& richness in connecting people to nature. PloS One, 10 (11), e0141505. https://doi.org/10.1371/journal.pone.0141505

Cronin, B. \& Sugimoto, C.R. (2014) Beyond Bibliometrics: Harnessing Multidimensional Indicators of Scholarly Impact. MIT Press, Cambridge, MA, $480 \mathrm{pp}$.

Crous, P.W. (2005) Impact of molecular phylogenetics on the taxonomy and diagnostics of fungi. EPPO Bulletin, 35 (1), $47-51$. https://doi.org/10.1111/j.1365-2338.2005.00811.x

Silva, M. (2019) Brazil, example of a non-Nagoya Protocol country. Microbiology Australia, 40 (3), 106-108.

Daily, G.C., Söderqvist, T., Aniyar, S., Arrow, K., Dasgupta, P., Ehrlich, P.R., Folke, C., Jansson, A., Jansson, B.O., Kautsky, N. \& Levin, S. (2000) The value of nature and the nature of value. Science, 289 (5478), 395-396. https://doi.org/10.1126/science.289.5478.395

Dalton, R. (2006) Biodiversity: cashing in on the rich coast. Nature, $441,567-569$. https://doi.org/10.1038/441567a

Darlington Jr, P.J. (1971) Modern taxonomy, reality, and usefulness. Systematic Zoology, 20 (3), 341-365. https://doi.org/10.2307/2412346

Deans, A.R., Yoder, M.J. \& Balhoff, J.P. (2012) Time to change how we describe biodiversity. Trends in Ecology \& Evolution, 27 (2), 78-84. https://doi.org/10.1016/j.tree.2011.11.007

DeGeer, M.E. (2003) Biopiracy: the appropriation of indigeous Peoples' cultural knowledge. New England Journal of International and Comparative Law, 9 (1), 179-208.

Delsuc, F., Brinkmann, H. \& Philippe, H. (2005) Phylogenomics and the reconstruction of the tree of life. Nature Review Genetics, 6, 361-375. https://doi.org/10.1038/nrg1603

Desmazières, J.B.H.J. (1823) Catalogue des Plantes Ommises dans la Botanographie Belgique et dans les Flores du Nord de la France. Leleux, Lille, 107 pp.

Desmazières, J.B.H.J. (1827) Recherches microscopiques et physiologiques sur le genre Mycoderma. Annales des Sciences Naturelles Botanique, 10, 42-67.

De Silva, D.D., Rapior, S., Sudarman, E., Stadler, M., Xu, J., Alias, S.A. \& Hyde, K.D. (2013) Bioactive metabolites from macrofungi: ethnopharmacology, biological activities and chemistry. Fungal Diversity, 62 (1), 1-40. https://doi.org/10.1007/s13225-013-0265-2

Díaz, S., Pascual, U., Stenseke, M., Martín-López, B., Watson, R.T., Molnár, Z., Hill, R., Chan, K.M., Baste, I.A., Brauman, 
K.A. Polasky, S., Church, A., Lonsdale, M., Larigauderie, A., Leadley, P.W., van Oudenhoven, A. P. E., van der Plaat, F., Schröter, M., Lavorel, S., Aumeeruddy-Thomas, Y., Bukvareva, E., Davies, K., Demissew, S., Erpul, G., Failler, P., Guerra, C.A., Hewitt, C.L., Keune, H., Lindley, S. \& Shirayama, Y. (2018) Assessing nature's contributions to people. Science, 359 (6373), 270-272.

https://doi.org/10.1126/science.aap8826

Díaz-Escandón, D., Soto Medina, E., Lücking, R. \& Silverstone Sopkin, P. (2015) Corticolous lichens as environmental indicators of natural sulphur emissions near the sulphur mine El Vinagre (Cauca, Colombia). The Lichenologist, 47, 147159.

https://doi.org/10.1017/S0024282915000535

Disney, H. (2000) Hands-on taxonomy. Nature, 405, 619. https://doi.org/10.1038/35015154

Drew, L.W. (2011) Are we losing the science of taxonomy? As need grows, numbers and training are failing to keep up. BioScience, 61 (12), 942-946.

https://doi.org/10.1525/bio.2011.61.12.4

Drummond, A.J., Suchard, M.A., Xie, D. \& Rambaut, A. (2012) Bayesian phylogenetics with BEAUti and the BEAST 1.7. Molecular Biology and Evolution, 29 (8), 1969-1973. https://doi.org/10.1093/molbev/mss075

Dubois, A. (2003) The relationships between taxonomy and conservation biology in the century of extinctions. Comptes Rendus Biologies, 326, 9-21.

https://doi.org/10.1016/S1631-0691(03)00022-2

Duraiappah, A.K. \& Rogers, D. (2011) The Intergovernmental PlatformonBiodiversityandEcosystemServices:opportunities for the social sciences. Innovation: The European Journal of Social Science Research, 24 (3), 217-224.

https://doi.org/10.1080/13511610.2011.592052

Dwyer, L. (2008) Biopiracy, trade, and sustainable development. Colorado Journal of International Environmental Law and Policy, 19, 219-259.

Ebach, M.C., Valdecasas, A.G. \& Wheeler, Q.D. (2011) Impediments to taxonomy and users of taxonomy: accessibility and impact evaluation. Cladistics, 27 (5), 550-557. https://doi.org/10.1111/j.1096-0031.2011.00348.x

Ehrlich, P.R. \& Pringle, R.M. (2008) Where does biodiversity go from here? A grim business-as-usual forecast and a hopeful portfolio of partial solutions. Proceedings of the National Academy of Sciences, 105 (Supplement 1), 11579-11586. https://doi.org/10.1073/pnas.0801911105

Ellis, R., Waterton, C. \& Wynne, B. (2010) Taxonomy, biodiversity and their publics in twenty-first-century DNA barcoding. Public Understanding of Science, 19 (4), 497-512. https://doi.org/10.1177/0963662509335413

Ereshefsky, M. (2002) Linnaean ranks: vestiges of a bygone era. Philosophy of Science, 69 (53), S305-S315.

Ereshefsky, M. (2007) Species, taxonomy, and systematics. In: Matthen, M. \& Stephens, C. (Eds.), Philosophy of Biology. North-Holland (Elsevier), Amsterdam, pp 403-427. https://doi.org/10.1016/B978-044451543-8/50020-4

Evenhuis, N.L. (2007) Helping solve the "other" taxonomic impediment: completing the eight steps to total enlightenment and taxonomic nirvana. Zootaxa, 1407 (3-12), 67-68. https://doi.org/10.11646/zootaxa.1407.1.2

Figueiredo, E. \& Smith, G.F. (2010) The colonial legacy in African plant taxonomy. South African Journal of Science, 106 (3-4), $1-4$.

https://doi.org/10.4102/sajs.v106i3/4.161
Flakus, P.R. \& Printzen, C. (2014) Palicella, a new genus of lichenized fungi and its phylogenetic position within Lecanoraceae. The Lichenologist, 46 (4), 535-552. https://doi.org/10.1017/S0024282914000127

Franco, F.M., Hidayati, S., Ghani, B.A.A. \& Ranaivo-Malancon, B. (2015) Ethnotaxonomic systems can reflect the vitality status of indigenous languages and traditional knowledge. Indian Journal of Traditional Knowledge, 14 (2), 175-182.

Funk, V.A. \& Stuessy, T.F. (1978) Cladistics for the practicing plant taxonomist. Systematic Botany, 3 (2), 159-178. https://doi.org/10.2307/2418311

Galagan, J.E., Calvo, S.E., Borkovich, K.A., Selker, E.U., Read, N.D., Jaffe, D., FitzHugh, W., Ma, L.J., Smirnov, S., Purcell, S., Rehman, B., Elkins, T., Engels, R., Wang, S., Nielsen, C.B., Butler, J., Endrizzi, M., Qui, D., Ianakiev, P., Bell-Pedersen, D., Nelson, M.A., Werner-Washburne, M., Selitrennikoff, C.P., Kinsey, J.A., Braun, E.L., Zelter, A., Schulte, U., Kothe, G.O., Jedd, G., Mewes, W., Staben, C., Marcotte, E., Greenberg, D., Roy, A., Foley, K., Naylor, J., Stange-Thomann, N., Barrett, R., Gnerre, S., Kamal, M., Kamvysselis, M., Mauceli, E., Bielke, C., Rudd, S., Frishman, D., Krystofova, S., Rasmussen, C., Metzenberg, R.L., Perkins, D.D., Kroken, S., Cogoni, C., Macino, G., Catcheside, D., Li, W., Pratt, R. J., Osmani, S.A., DeSouza, C. P., Glass, L., Orbach, M. J., Berglund, J.A., Voelker, R., Yarden, O., Plamann, M., Seiler, S., Dunlap, J., Radford, A., Aramayo, R., Natvig, D.O., Alex, L.A., Mannhaupt, G., Ebbole, D.J., Freitag, M., Paulsen, I., Sachs, M.S., Lander, E.S., Nusbaum, C. \& Birren, B. (2003) The genome sequence of the filamentous fungus Neurospora crassa. Nature, 422 (6934), 859-868. https://doi.org/10.1038/nature01554

Gewin, V. (2002) All living things, online. Nature, 418, 362-363. https://doi.org/10.1038/418362a

Giangrande, A. (2003) Biodiversity, conservation, and the 'Taxonomic impediment'. Aquatic Conservation: Marine and Freshwater Ecosystems, 13 (5), 451-459.

https://doi.org/10.1002/aqc.584

Gilmour, J.S. (1951) The development of taxonomic theory since 1851. Nature, 168 (4271), 400-402. https://doi.org/10.1038/168400a0

Godfray, H.C.J. (2002) Challenges for taxonomy. Nature, 417 (6884), 17-19. https://doi.org/10.1038/417017a

Goëau, H., Bonnet, P., Joly, A., Bakić, V., Barbe, J., Yahiaoui, I., Selmi, S., Carré, J., Barthélémy, D., Boujemaa, N. \& Molino, J. F. (2013) Pl@ ntnet mobile app. Proceedings of the 21st ACM International Conference on Multimedia, MM '13, 423-424. https://doi.org/10.1145/2502081.2502251

Andrade-C., M.G. (2012) Problematica para la Obtención de Permisos de Investigación y Contratos de Acceso a Recursos Genéticos en Colombia. Available from: https://sites.google. $\mathrm{com} / \mathrm{site} / \mathrm{mgandradec} /$ problematica-para-la-obtencion-depermisos-de-investigacion-y-contratos-de-acceso-a-recursosgeneticos-en-colombia (accessed 28 January 2020)

González Medina, J.P. (2016) Biologists, Policymakers and Other Specimens: A Story About Collecting, Regulating and Social Interactions. Doctoral Dissertation, Universidad Nacional de Colombia, Bogotá, 387 pp.

Goyes, D.R. \& South, N. (2015) Land-grabs, biopiracy and the inversion of justice in Colombia. British Journal of Criminology, 56 (3), 558-577.

https://doi.org/10.1093/bjc/azv082 
Grajal, A. (1999) Biodiversity and the nation state: Regulating access to genetic resources limits biodiversity research in developing countries. Conservation Biology, 13 (1), 6-10.

Granjou, C., Mauz, I., Barbier, M. \& Breucker, P. (2014) Making taxonomy environmentally relevant. Insights from an all taxa biodiversity inventory. Environmental Science \& Policy, 38, 254-262.

https://doi.org/10.1016/j.envsci.2014.01.004

Grassi, M.M. (1950) Los liquenes foliosos y fruticulosos de Tucuman. Lilloa, 24, 297-395.

Grewe, F., Lagostina, E., Wu, H., Printzen, C. \& Lumbsch, H.T. (2018) Population genomic analyses of RAD sequences resolves the phylogenetic relationship of the lichen-forming fungal species Usnea antarctica and Usnea aurantiacoatra. MycoKeys, 43, 91-113. https://doi.org/10.3897/mycokeys.43.29093

Groenewald, J.Z., Groenewald, M. \& Crous, P.W. (2011) Impact of DNA data on fungal and yeast taxonomy. Microbiology Australia, 32 (2), 100-104.

Guerra-García, J.M., Espinosa Torre, F. \& García-Gómez, J.C. (2008) Trends in taxonomy today: an overview about the main topics in taxonomy. Zoológica Baetica, 19, 15-49.

Habel, J.C., Eggermont, H., Günter, S., Mulwa, R.K., Rieckmann, M., Koh, L.P., Niassy, S., Ferguson, J.W. H., Gebremichael, G., Githiru, M. \& Weisser, W.W. (2014) Towards more equal footing in north-south biodiversity research: European and sub-Saharan viewpoints. Biodiversity and Conservation, 23 (12), 3143-3148.

https://doi.org/10.1007/s10531-014-0761-z

Hallwachs, W., Gámez, R. \& Janzen, D.H. (1993) The role of the parataxonomists, curators and international taxonomists in Costa Rica's National Biodiversity Inventory. In: Reid, W.V., Laird, S.A., Meyer, C.A., Gámez, R., Sittenfeld, A., Janzen, D.H., Gollin, M.A. \& Juma C. (Eds.), Biodiversity Prospecting. World Resources Institute, Washington, D.C., pp. 223-254.

Halme, P., Kuusela, S. \& Juslén, A. (2015) Why taxonomists and ecologists are not, but should be, carpooling? Biodiversity and Conservation, 24 (7), 1831-1836. https://doi.org/10.1007/s10531-015-0899-3

Hamilton, C. (2006) Biodiversity, biopiracy and benefits: what allegations of biopiracy tell us about intellectual property. Developing World Bioethics, 6, 158-173. https://doi.org/10.1111/j.1471-8847.2006.00168.x

Hammond, P.M. (1992) Species inventory. In: Groombridge, B. (Ed.), Global Biodiversity: Status of the Earth's Living Resources. Chapman \& Hall, London, pp. 17-39.

Harvey, A.L. (2007) Natural products as a screening resource. Current Opinion in Chemical Biology, 11 (5), 480-484. https://doi.org/10.1016/j.cbpa.2007.08.012

Hawksworth, D.L. (1991) The fungal dimension of biodiversity: magnitude, significance and conservation. Mycological Research, 95, 641-655.

https://doi.org/10.1016/S0953-7562(09)80810-1

Hawksworth, D.L. (2001) The magnitude of fungal diversity: the 1.5 million species estimate revisited. Mycological Research, $105,1422-1432$.

https://doi.org/10.1017/S0953756201004725

Hawksworth, D.L. (2004) Rediscovery of the original material of Osbeck's Lichen chinensis and the re-instatement of the name Parmotrema perlatum (Parmeliaceae). Herzogia, 17, 37-44.

Hawksworth, D.L. (2012) Global species numbers of fungi: are tropical studies and molecular approaches contributing to a more robust estimate? Biodiversity and Conservation, 21 (9), $2425-2433$.

https://doi.org/10.1007/s10531-012-0335-x

Hawksworth, D.L. \& Lücking, R. (2018) Fungal diversity revisited: 2.2 to 3.8 million species. In: Heitman, J., Howlett, B.J., Crous, P.W., Stukenbrock, E.H., James, T.Y. \& Gow, N.A.R. (Eds.), The Fungal Kingdom. American Society for Microbiology, Washington, DC, pp. 79-95. https://doi. org/10.1128/microbiolspec.FUNK-0052-2016

Hawksworth, D.L. \& Rossman, A.Y. (1997) Where are all the undescribed fungi? Phytopathology, 87, 888-891. https://doi.org/10.1094/PHYTO.1997.87.9.888

Helaly, S.E., Thongbai, B. \& Stadler, M. (2018) Diversity of biologically active secondary metabolites from endophytic and saprotrophic fungi of the ascomycete order Xylariales. Natural Product Reports, 35 (9), 992-1014. https://doi.org/10.1039/C8NP00010G

Herrera-Campos, M.A., Clerc, P. \& Nash, TH. III (1998) Pendulous species of Usnea from the temperate forests in Mexico. The Bryologist, 101 (2), 303-329. https://doi.org/10.2307/3244208

Hert, D.G., Fredlake, C.P. \& Barron, A.E. (2008) Advantages and limitations of next-generation sequencing technologies: a comparison of electrophoresis and non-electrophoresis methods. Electrophoresis, 29 (23), 4618-4626. https://doi.org/10.1002/elps.200800456

Heyd, T. (2016) Encountering Nature: Toward an Environmental Culture. Routledge, London, New York, 206 pp.

Homchantara, N. \& Coppins, B.J. (2002) New species of the lichen family Thelotremataceae in SE Asia. The Lichenologist, 34 (2), 113-140. https://doi.org/10.1006/lich.2002.0382

Horrell, D.G. (2015) The Bible and the Environment: Towards a Critical Ecological Biblical Theology. Routledge, London, New York, $172 \mathrm{pp}$.

Hutchings, P. (2013) Why are taxonomists often regarded as second class citizens? A misclassification that threatens the basic infrastructure of biodiversity. In: Lunney, D., Hutchings, P. \& Recher, H. F. (Eds.), Grumpy Scientists: the Ecological Conscience of a Nation. Royal Zoological Society of New South Wales, Mosman, pp. 26-30. https://doi.org/10.7882/FS.2013.009

Hyde, K.D., Xu, J.C., Rapior, S., Jeewon, R., Lumyong, S., Niego, A.G.T., Abeywickrama, P.D., Aluthmuhandiram, J.P.S., Brahamanage, R.S., Brooks, S., Chaiyasen, A., Chethana, K.W.T., Chomnunti, P., Chepkirui, K., Chuankid, B., de Silva, N.I., Doilom, M., Faulds, C., Gentekaki, E., Gopalan, V., Kakumyan, P., Harishchandra, D., Hemachandran, H., Hongsanan, S., Karunarathna, A., Karunarathna, S.C., Khan, S., Kumla, J., Jayawardena, R.S., Liu, N., Luangharn, T., Macabeo, A.P.G., Marasinghe, D.S., Meeks, D., Mortimer, P.E., Mueller, P., Nadir, S., Nataraja, K. N., Nontachaiyapoom, S., O'Brien, M., Penkhrue, W., Phukhamsakda, C., Shaanker Ramanan, U., Rathnayaka, A.R., Sadaba, R.S., Sandargo, B., Samarakoon, B.C., Tennakoon, D.S., Siva, R., Sriprom, W., Suryanarayanan, T.S., Sujarit, K., Suwannarach, N., Suwunwong, T., Thongbai, B., Thongklang, N., Wei, D., Wijesinghe, N.S., Winiski, J., Yan, J., Yasanthika, E. \& Stadler, M. (2019) The amazing potential of fungi, 50 ways we can exploit fungi industrially. Fungal Diversity, 97, 1-136. https://doi.org/10.1007/s13225-019-00430-9

Index Fungorum (2020) Index Fungorum. Available from: http:// www.indexfungorum.org/Names/Names.asp (accessed 28 January 2020) 
International Field Guides (2020) International Field Guides Database. Available from: https://www.library.illinois.edu/ biology/fieldguides (accessed 28 January 2020)

International Innovation (2012) Looking for Lichen. International Innovation, 2012 (August), 92-94.

Isaac, N.J., Mallet, J. \& Mace, G.M. (2004) Taxonomic inflation: its influence on macroecology and conservation. Trends in Ecology \& Evolution, 19 (9), 464-469. https://doi.org/10.1016/j.tree.2004.06.004

Janzen, D.H. (1991) How to save tropical biodiversity: the National Biodiversity Institute of Costa Rica. American Entomologist, 37 (3), 159-171.

https://doi.org/10.1093/ae/37.3.159

Jatnika, M.F., Weerakoon, G., Arachchige, O., Noer, I.S., Voytsekhovich, A. \& Lücking, R. (2019) Discoveries through social media and in your own backyard: two new species of Allographa (Graphidaceae) with pigmented lirellae from the Palaeotropics, with a world key to species of this group. The Lichenologist, 51 (3), 227-233.

https://doi.org/10.1017/S0024282919000094

Jennings, W. \& Wlezien, C. (2018) Election polling errors across time and space. Nature Human Behaviour, 2 (4), 276-283. https://doi.org/10.1038

Johnsgard, P.A. (2006) A book-collector's guide to Roger Tory Peterson. Nebraska Bird Review, 74, 61-64.

Joly, A., Bonnet, P., Goëau, H., Barbe, J., Selmi, S., Champ, J., Dufour-Kowalski, S., Affouard, A., Carré, J., Molino, J. F. \& Boujemaa, N. (2016) A look inside the P1@ntNet experience. Multimedia Systems, 22 (6), 751-766. https://doi.org/10.1007/s00530-015-0462-9

Joppa, L.N., Roberts, D.L. \& Pimm, S.L. (2011) The population ecology and social behaviour of taxonomists. Trends in Ecology \& Evolution, 26 (11), 551-553. https://doi.org/10.1016/j.tree.2011.07.010

Judd, W.S., Campbell, C.S., Kellogg, E.A., Stevens, P.F. \& Donoghue, M.J. (2007) Plant Systematics: A Phylogenetic Approach (3rd ed.). Sinauer Associates, Sunderland, 611 pp.

Kazmier, R.M. (2017) The Parataxonomist Revolution: How a Group of Rural Costa Ricans Discovered 10,000 New Species. Doctoral Dissertation, Massachusetts Institute of Technology, Boston.

Kay, J. (1989) Human dominion over nature in the Hebrew Bible. Annals of the Association of American Geographers, 79 (2), 214-232. https://doi.org/10.1111/j.1467-8306.1989.tb00259.x

Kealey, T. (1996) The Economic Laws of Scientific Research. Macmillan, London, $396 \mathrm{pp}$

Kim, K.C. \& Byrne, L.B. (2006) Biodiversity loss and the taxonomic bottleneck: emerging biodiversity science. Ecological Research, 21 (6), 794-810. https://doi.org/10.1007/s11284-006-0035-7

Kirika, P.M., Divakar, P.K., Buaruang, K., Leavitt, S.D., Crespo, A., Gatheri, G.W., Mugambi, G., Benatti, M.N. \& Lumbsch, H.T. (2017) Molecular phylogenetic studies unmask overlooked diversity in the tropical lichenized fungal genus Bulbothrix sl (Parmeliaceae, Ascomycota). Botanical Journal of the Linnean Society, 184 (3), 387-399. https://doi.org/10.1093/botlinnean/box027

Kirika, P.M., Divakar, P.K., Crespo, A. \& Lumbsch, H.T. (2019) Molecular and phenotypical studies on species diversity of Hypotrachyna (Parmeliaceae, Ascomycota) in Kenya, East Africa. The Bryologist, 122 (1), 140-150. https://doi.org/10.1639/0007-2745-122.1.140
Kirk, P.M., Cannon, P.F., Minter, D.W. \& Stalpers, J.A. (eds.) (2008) Taxonomy. In: Dictionary of the Fungi, 10th Edition. CABI, Netherlands, pp. 147, 679.

Kitching, I.J., Forey, P., Humphries, C. \& Williams, D. (1998) Cladistics: The Theory and Practice of Parsimony Analysis (The Systematics Association No. 11). Oxford University Press, Oxford, New York, xiii +228 pp.

Kitching, R.L. (1993) Biodiversity and taxonomy: impediment or opportunity. In: Moritz, C. \& Kikkawa, J. (Eds.), Conservation Biology in Australia and Oceania. Surrey Beatty \& Sons, pp. 253-268.

Koch, M.A., German, D.A., Kiefer, M. \& Franzke, A. (2018) Database taxonomics as key to modern plant biology. Trends in Plant Science, 23 (1), 4-6. https://doi.org/10.1016/j.tplants.2017.10.005

Koehn, F.E. (2008) High impact technologies for natural products screening. In: Petersen, F. \& Amstutz, R. (Eds.), Natural Compounds as Drugs, Volume I. Birkhäuser, Basel, pp. 175210.

Korf, R.P. (2005) Reinventing taxonomy: a curmudgeon's view of 250 years of fungal taxonomy, the crisis in biodiversity, and the pitfalls of the phylogenetic age. Mycotaxon, 93, 407-416.

Kraichak, E., Divakar, P.K., Crespo, A., Leavitt, S.D., Nelsen, M.P., Lücking, R. \& Lumbsch, H.T. (2015) A tale of two hyper-diversities: diversification dynamics of the two largest families of lichenized fungi. Scientific Reports, 5, 10028. https://doi.org/10.1038/srep10028

Krishnamurthy, K.V. \& Adams, S.J. (2016) Ethnoecology, ethnotaxonomy, and ethnonomenclature of plants of ancient Tamils. In: Pullaiah, T., Krishnamurthy, K. V. \& Bahadur, B. (Eds.), Ethnobotany of India, Volume 1. Apple Academic Press, pp. 95-114.

Krolzik, U. (1980) Umweltkrise-Folge des Christentums? 2. Auflage, Kreuz, Stuttgart, 125 pp.

Kupferschmidt, K. (2018) Biologists raise alarm over changes to biopiracy rules. Science, 361 (6397), 14. https://doi.org/10.1126/science.361.6397.14

La Salle, J., Wheeler, Q., Jackway, P., Winterton, S., Hobern, D. \& Lovell, D. (2009) Accelerating taxonomic discovery through automated character extraction. Zootaxa, 2217 (1), 43-55. httpS://doi.org/10.11646/zootaxa.2217.1.3

Lahlou, M. (2007) Screening of natural products for drug discovery. Expert Opinion on Drug Discovery, 2 (5), 697-705. https://doi.org/10.1517/17460441.2.5.697

Laird, S. \& Wynberg, R. (2018) A fact-finding and scoping study on digital sequence information on genetic resources in the context of the Convention on Biological Diversity and the Nagoya Protocol. Available from: https://www.cbd.int/doc/ c/b39f/4faf/7668900e8539215e7c7710fe/dsi-ahteg-2018-0103-en.pdf (accessed 28 January 2020)

Law, J. \& Lynch, M. (1988) Lists, field guides, and the descriptive organization of seeing: birdwatching as an exemplary observational activity. Human Studies, 11 (2/3), 271-303.

Leakey, R., Lewin, R. \& Lovejoy, T.E. (1996) The sixth extinction: biodiversity and its survival. Nature, 382 (6592), 594.

Lew, K. (2018) Taxonomy: The Classification of Biological Organisms. Enslow, Berkeley Heights, NJ, 80 pp.

Lewis, W.H.\& Ramani, V.(2007)Ethics and practice in ethnobiology: analysis of the International Cooperative Biodiversity Group project in Peru. In: McManis, C. R. (Ed.), Biodiversity and the Law: Intellectual Property, Biotechnology and Traditional Knowledge. Routledge, pp. 394-412. 
Linnaeus, C. (1753) Species Plantarum. Tomus I. Salvius, Holm, $1242 \mathrm{pp}$.

Linnaeus, C. (1758) Systema Naturae. Tomus I. Editio Decima, Reformata. Salvius, Holm, 828 pp.

Lücking, R. (1999) Foliicolous lichens and their lichenicolous fungi from Ecuador, with a comparison of lowland and montane rainforest. Willdenowia, 29, 299-335.

Lücking, R. (2019) Stop the abuse of time! A critical review of temporal banding for rank-based classifications in Fungi (including lichens) and other organisms. Critical Review in Plant Sciences, 38, 199-253. https://doi.org/10.1080/07352689.2019.1650517

Lücking, R., Sipman, H.J.M. \& Umaña Tenorio, L. (2004) TICOLICHEN-The Costa Rican lichen biodiversity inventory as a model for lichen inventories in the tropics. In: The 5th IAL Symposium Lichens in Focus (Vol. 32).

Lücking, R., Aptroot, A., Umaña, L., Chaves, J.L., Sipman, H.J.M. \& Nelsen, M.P. (2006) A first assessment of the TICOLICHEN biodiversity inventory in Costa Rica: the genus Gyalideopsis and its segregates (Ostropales: Gomphillaceae), with a worldwide key and name status checklist. The Lichenologist, 38 (2), 131-160 https://doi.org/10.1017/S0024282905005657

Lücking, R., Aptroot, A., Chaves, J.L., Sipman, H.J.M. \& Umana, L. (2007) A first assessment of the TICOLICHEN biodiversity inventory in Costa Rica: the genus Coccocarpia (Peltigerales: Coccocarpiaceae). Bibliotheca Lichenologica, 95, 429-457.

Lücking, R., Chaves, J.L., Sipman, H.J.M., Umaña, L. \& Aptroot, A. (2008) A first assessment of the TICOLICHEN biodiversity inventory in Costa Rica: the genus Graphis, with notes on the genus Hemithecium (Ascomycota: Ostropales: Graphidaceae) Fieldiana (Botany), 46), 1-126.

https://doi.org/10.3158/0015-0746(2008)46[1: AFAOTT]2.0.CO;2

Lücking, R., Dal Forno, M., Sikaroodi, M., Gillevet, P.M., Bungartz, F., Moncada, B., Yánez-Ayabaca, A., Chaves, J.L., Coca, L.F. \& Lawrey, J.D. (2014) A single macrolichen constitutes hundreds of unrecognized species. Proceedings of the National Academy of Sciences, 111, 11091-11096. https://doi.org/10.1073/pnas.1403517111

Lücking, R., Dal Forno, M., Moncada, B., Coca, L. F., VargasMendoza, 1.Y., Aptroot, A., Arias, L.J., Besal, B., Bungartz, F., Cabrera-Amaya, D.M., Cáceres, M.E.S., Chaves, J.L., Eliasaro, S., Gutiérrez, M.C., Hernández-M., J.E., HerreraCampos, M.A., Holgado-Rojas, M.E., Jonitz, H., Kukwa, M., Lucheta, F., Madriñán, S., Marcelli, M.P., Martins, S.M.A., Mercado-Díaz, J.A., Molina, J.A., Morales, E.A., Nelson, P.R., Nugra, F., Ortega, F., Paredes, T., Patiño, A.L., Peláez-Pulido, R.N., Pérez-Pérez, R.E., Perlmutter, G.B., Rivas-Plata, M.E., Robayo, J., Rodríguez, C., Simijaca, D.F., Soto-Medina, E., Spielmann, A.A., Suárez-Corredor, A., Torres, J.M., Vargas, C.A., Yánez-Ayabaca, A., Weerakoon, G., Wilk. K., CelisPacheco, M., Diazgranados, M., Brokamp, G., Borsch, T., Gillevet, P.M., Sikaroodi, M. \& Lawrey, J.D. (2016) Turbo-taxonomy to assemble a megadiverse lichen genus: seventy new species of Cora (Basidiomycota: Agaricales: Hygrophoraceae), honouring David Leslie Hawksworth's seventieth birthday. Fungal Diversity, 84, 139-207. https://doi.org/10.1007/s13225-016-0374-9

Lyal, C., Kirk, P., Smith, D. \& Smith, R. (2008) The value of taxonomy to biodiversity and agriculture. Biodiversity, 9 (1-2), 8-13.

https://doi.org/10.1080/14888386.2008.9712873
Mair, J. (2012) Die globale Umweltkrise als Folge des Christentums? Eine kritische Würdigung der provokanten These Lynn T. Whites. GRIN, München, 16 pp.

Manktelow, M. (2010) History of Taxonomy. Lecture from Dept. of Systematic Biology, Uppsala University. Available from: http://www.atbi.eu/summerschool/files/summerschool/ Manktelow_Syllabus.pdf (accessed 28 January 2020)

Mann, T. (2015) The Oxford Guide to Library Research. Oxford University Press, $320 \mathrm{pp}$.

Marcelli, M.P., Jungbluth, P., Benatti, M.N., Spielmann, A.A., Canêz, L.S., Cunha, I.P.R. \& Martins, M.F. N. (2007) Some new species and combinations of Brazilian lichenized fungi. Bibliotheca Lichenologica, 96, 209-227.

Mauthner, N.S. \& Parry, O. (2013) Open access digital data sharing: Principles, policies and practices. Social Epistemology, 27 (1), 47-67. https://doi.org/10.1080/02691728.2012.760663

Mawatari, S.F. (2004) Taxonomy: a discipline central to integrative biology. Neo-Science of Natural History: Integration of Geoscience and Biodiversity Studies: Proceedings of International Symposium on" Dawn of a New Natural HistoryIntegration of Geoscience and Biodiversity Studies" March 5-6, 2004, Sapporo. Graduate School of Science, Hokkaido University, pp. 29-39.

May, R.M. (2000) The dimensions of Life on Earth. In: Raven, P. H. \& Williams, T. (Eds.), Nature and Human Society: The Quest for a Sustainable World. National Academy Press, Washington, DC, pp. 30-45.

Mayo, S.J., Allkin, R., Baker, W., Blagoderov, V., Brake, I., Clark, B., Govaerts, R., Godfray, C., Haigh, A., Hand, R., Harman, K., Jackson, M., Kilian, N., Kirkup, D.W., Kitching, I., Knapp, S., Lewis, G.P., Malcolm, P., von Raab-Straube, E., Roberts, D.M., Scoble, M., Simpson, D.A., Smith, C., Smith, V., Villalba, S., Walley, L. \& Wilkin, P. (2008) Alpha etaxonomy: responses from the systematics community to the biodiversity crisis. Kew Bulletin, 63 (1), 1-16. https://doi.org/10.1007/s12225-008-9014-1

Mayr, E. (1968) The role of systematics in biology. Science, 159 (3815), 595-599. https://doi.org/10.1126/science.159.3815.595

Mayr, E. (1982a). Chapter 6: Microtaxonomy, the science of species. In: Mayr, E. (Eds.), The Growth of Biological Thought: Diversity, Evolution, and Inheritance. Belknap Press, Harvard University Press, pp. 251-297.

Mayr, E. (1982b) The Growth of Biological Thought. Belknap Press, Harvard University press, Cambridge, MA.

Meierotto, S., Sharkey, M.J., Janzen, D.H., Hallwachs, W., Hebert, P.D., Chapman, E.G. \& Smith, M.A. (2019) A revolutionary protocol to describe understudied hyperdiverse taxa and overcome the taxonomic impediment. Deutsche Entomologische Zeitschrift, 66, 119-145. https://doi.org/10.3897/dez.66.34683

Menezes, A.A., Cáceres, M.E.S., Bastos, C.J.P. \& Lücking, R. (2018) The latitudinal diversity gradient of epiphytic lichens in the Brazilian Atlantic Forest: does Rapoport's rule apply? The Bryologist, 121 (4), 480-497. https://doi.org/10.1639/0007-2745-121.4.480

Merriam, F. (1898) Birds Through an Opera Glass. (The Riverside Library for Young People Number 3). Riverside Press, Cambridge, $225 \mathrm{pp}$.

Merson, J. (2000) Bio-prospecting or bio-piracy: intellectual property rights and biodiversity in a colonial and postcolonial context. Osiris, 15, 282-296. https://doi.org/10.1086/649331 
Meyen, J. (1838) Jahresbericht über die Resultate der Arbeiten im Felde der physiologischen Botanik v. d. Jahre 1837. Archiv für Naturgeschichte, 4 (2), 1-186.

Meyer, S.M. (1997) The economic impact of the Endangered Species Act on the housing and real estate markets. NYU Environmental Law Journal, 6 (2), 450-478.

Miller, J.R. (2005) Biodiversity conservation and the extinction of experience. Trends in Ecology \& Evolution, 20 (8), 430-434. https://doi.org/10.1016/j.tree.2005.05.013

Minelli, A. (2012) Biological Systematics: The State of the Art. Springer.

Molina, M.C., Divakar, P.K., Goward, T., Millanes, A.M., Lumbsch, H.T. \& Crespo, A. (2017) Neogene diversification in the temperate lichen-forming fungal genus Parmelia (Parmeliaceae, Ascomycota). Systematics and Biodiversity, 15 (2), 166-181. https://doi.org/10.1080/14772000.2016.1226977

Moncada, B. (2012) El Género Sticta (Schreb.) Ach. en Colombia: Taxonomía, Ecogeografia Importancia. DoctoralDissertation, Universidad Nacional de Colombia, Bogotá, 418 pp.

Moncada, B., Aguirre-C., J. \& Lücking, R. (2014) Ecogeografía del género Sticta (Ascomycota liquenizados: Lobariaceae) en Colombia. Revista de Biologia Tropical, 62 (1), 257-272.

Mohanta, T.K. \& Bae, H. (2015) The diversity of fungal genome. Biological Procedures Online, 17(1), 8. https://doi.org/10.1186/s12575-015-0020-z

Mora, C., Tittensor, D.P., Adl, S., Simpson, A.G. \& Worm, B. (2011) How many species are there on Earth and in the ocean? PLoS Biology, 9 (8), e1001127. https://doi.org/10.1371/journal.pbio.1001127

Mors, W.B. (1952) Investigações químicas sobre liquens brasileiros: estudos da Usneae da Serra dos Órgãos. Boletim do Instituto de Química Agrícola, 29: 1-23.

Motta, K., Amórtegui, K., Moncada, B. \& Lücking, R. (2019) New species in the genera Graphis with transversally septate ascospores (Ascomycota: Ostropales: Graphidaceae) from Colombia. Phytotaxa, 401, 257-266.

https://doi.org/10.11646/phytotaxa.401.4.3

Mullin, R. (2008) Merck cuts sales jobs and halts natural products research. Chemical and Engineering News, 86 (19), 12.

Myers, N., Mittermeier, R. A., Mittermeier, C.G., Da Fonseca, G.A. \& Kent, J. (2000) Biodiversity hotspots for conservation priorities. Nature, 403 (6772), 853-858. https://doi.org/10.1038/35002501

Nash, T.H. III, Ryan, B.D., Gries, C. \& Bungartz, F. (Eds.) (2002) Lichen Flora of the Greater Sonoran Desert Region. Volume 1. Lichens Unlimited, Arizona State University, Tempe, 532 pp.

Nash, T.H. III, Ryan, B.D., Diederich, P., Gries, C. \& Bungartz, F. (Eds.) (2004) Lichen Flora of the Greater Sonoran Desert Region. Volume 2. Lichens Unlimited, Arizona State University, Tempe, $742 \mathrm{pp}$.

Nash, T.H. III, Gries, C. \& Bungartz, F. (Eds.) (2007) Lichen Flora of the Greater Sonoran Desert Region. Volume 3. Lichens Unlimited, Arizona State University, Tempe, $567 \mathrm{pp}$.

Nelsen, M.P., Lücking, R., Chaves, J.L., Sipman, H.J.M., Umana, L. \& Navarro, E. (2006) A first assessment of the TICOLICHEN biodiversity inventory in Costa Rica: the genus Haematomma (Lecanorales: Lecanoraceae). The Lichenologist, 38 (3), 251-262. https://doi.org/10.1017/S0024282906005573

Nelson, R.R. (1959) The simple economics of basic scientific research. Journal of Political Economy, 67 (3), 297-306.

Niesenbaum, R.A. (2019) The integration of conservation, biodiversity, and sustainability. Sustainability, 11 (17), 4676. https://doi.org/10.3390/su11174676

Nisbet, E.K., Zelenski, J.A. \& Murphy, S.A. (2009) The nature relatedness scale: linking individuals' connection with nature to environmental concern and behaviour. Environment and Behaviour, 41, 715-740. https://doi.org/10.1177/0013916508318748

Notton, D. \& Stringer, C. (2010) Who is the type of Homo sapiens? Available from: https://www.iczn.org/outreach/faqs/\#faq-13 (accessed 28 January 2020)

Oberthür, S. \& Rosendal, G.K. (Eds.) (2013) Global Governance of Genetic Resources: Access and Benefit Sharing after the Nagoya Protocol. Routledge, London, New York, 268 pp.

O’Brien, H.E., Parrent, J.L., Jackson, J.A., Moncalvo, J.M. \& Vilgalys, R. (2005) Fungal community analysis by largescale sequencing of environmental samples. Applied and Environmenta Microbiology, 71 (9), 5544-5550.

https://doi.org/10.1128/AEM.71.9.5544-5550.2005

Olivier-Jimenez, D., Chollet-Krugler, M., Rondeau, D., Beniddir, M.A., Ferron, S., Delhaye, T., Allard, P. M., Wolfender, J.L., Sipman, H.J. M, Lücking, R. \& Boustie, J. (2019) A database of high-resolution MS/MS spectra for lichen metabolites. Scientific Data, 6 (1), 249.

https://doi.org/10.1038/s41597-019-0305-1

Orange, A., James, P.W. \& White, F.J. (2010) Microchemical Methods for the Identification of Lichens. Second Edition with Additions and Corrections. British Lichen Society, London, $101 \mathrm{pp}$.

Padial, J.M. \& De la Riva, I. (2007) Integrative taxonomists should use and produce DNA barcodes. Zootaxa, 1586, 67-68.

Page, L.M. (2008) Planetary biodiversity inventories as models for the new taxonomy. In: Wheeler, Q. D. (Ed.), The New Taxonomy. CRC Press, Boca Raton, pp. 55-62.

Papong, K., Corush, J., Mangold, A., Lücking, R. \& Lumbsch, H.T. (2009) Phylogenetic position of the foliicolous genus Chroodiscus (Ostropales, Ascomycota) inferred from nuclear and mitochondrial ribosomal DNA sequences. Fungal Diversity, 38, 147-153.

Pascoe, I.G. (1990) History of systematic mycology in Australia. In: Short, P. S. (Ed.), History of Systematic Botany in Australia. Australian Systematic Botany Society, South Yarra, pp. 259264.

Patterson, D.J., Cooper, J., Kirk, P.M., Pyle, R.L. \& Remsen, D.P. (2010) Names are key to the big new biology. Trends in Ecology \& Evolution, 25 (12), 686-691. https://doi.org/10.1016/j.tree.2010.09.004

Pearson, D.L. \& Shetterly, J.A. (2006) How do published field guides influence interactions between amateurs and professionals in entomology? American Entomologist, 52 (4), 246-252.

Pearson, D. L., Hamilton, A. L. and Erwin, T. L. (2011) Recovery plan for the endangered taxonomy profession. BioScience, 61 (1), 58-63.

https://doi.org/10.1525/bio.2011.61.1.11

Pennisi, E. (2013) Costa Rica's INBio facing government bailout. Available from: http://news.sciencemag.org/ environment/2013/04/costa-ricas-inbio-facing-governmentbailout (accessed 28 January 2020)

Piepenbring, M. (2007) Inventoring the fungi of Panama. Biodiversity and Conservation, 16 (1), 73-84. https://doi.org/10.1007/s10531-006-9051-8

Piepenbring, M. (2015a) Introduction to Mycology in the Tropics. APS Press, St. Paul, 366 pp. https://doi.org/10.1094/9780890546130 
Piepenbring, M. (2015b) Introducción a la Micología en los Trópicos. APS Press, St. Paul, 364 pp. https://doi.org/10.1094/9780890546147

Pingal, R. (2017) Iwokrama Fungal/Plant Bioprospecting Project 2000-2003-A Model for the Future? In: Paterson, R. \& Lima, N. (Eds.), Bioprospecting. Springer, Cham, pp. 167-196. https://doi.org/10.1007/978-3-319-47935-4_8

Platnick, N.I. (1979) Philosophy and the transformation of cladistics. Systematic Zoology, 28 (4), 537-546.

Prathapan, K.D., Pethiyagoda, R., Bawa, K.S., Raven, P.H. \& Rajan, P.D. (2018) When the cure kills - CBD limits biodiversity research. Science, 360 (6396), 1405-1406. https://doi.org/10.1126/science.aat 9844

Pratibha, P. \& Mahesh, C.S. (2016) GC-MS analysis and biological activities of medicinally important lichen: Parmelia perlata. International Journal of Pharmacognosy and Phytochemical Research, 8 (12), 1975-1985.

Rabitz, F. (2015) Biopiracy after the Nagoya Protocol: problem structure, regime design and implementation challenges. Brazilian Political Science Review, 9 (2), 30-53. https://doi.org/10.1590/1981-38212014000200010

Rampino, M.R. \& Shen, S.Z. (2019) The end-Guadalupian (259.8 Ma) biodiversity crisis: the sixth major mass extinction? Historical Biology. https://doi.org/10.1080/08912963.2019.1658096

Raffauf, R.F. (1996) Plant Alkaloids. A Guide to Their Discovery and Distribution. The Haworth Press, Binghamton, NY, xiii $+279 \mathrm{pp}$.

Ramírez-Morán, N.A., León-Gómez, M. \& Lücking, R. (2016) Uso de biotipos de líquenes como indicadores de perturbación en dos fragmentos de bosque andino, Reserva Biológica "Encenillo", Colombia. Caldasia, 38, 31-52. https://doi.org/10.15446/caldasia.v38n1.57821

Reboleira, A.S.P. \& Enghoff, H. (2016) Taxonomics-nextgeneration taxonomists. Organisms Diversity \& Evolution, $16(4), 679-680$. https://doi.org/10.1007/s13127-016-0287-1

Richardson, M., Maspero, M., Golightly, D., Sheffield, D., Staples, V. \& Lumber, R. (2017) Nature: a new paradigm for wellbeing and ergonomics. Ergonomics, 60 (2), 292-305. https://doi.org/10.1080/00140139.2016.1157213

Riedel, A., Sagata, K., Suhardjono, Y.R., Tänzler, R. \& Balke, M. (2013) Integrative taxonomy on the fast track-towards more sustainability in biodiversity research. Frontiers in Zoology, $10(1), 15$.

https://doi.org/10.1186/1742-9994-10-15

Rivas Plata, E. \& Lumbsch, H.T. (2011) Parallel evolution and phenotypic divergence in lichenized fungi: a case study in the lichen-forming fungal family Graphidaceae (Ascomycota: Lecanoromycetes: Ostropales). Molecular Phylogenetics and Evolution, 61 (1), 45-63. https://doi.org/10.1016/j.ympev.2011.04.025

Rivas Plata, E., Lücking, R., Aptroot, A., Sipman, H.J.M., Chaves, J.L., Umaña, L. \& Lizano, D. (2006) A first assessment of the TICOLICHEN biodiversity inventory in Costa Rica: the genus Coenogonium (Ostropales: Coenogoniaceae), with a world-wide key and checklist and a phenotype-based cladistic analysis. Fungal Diversity, 23, 255-321.

Rizzini, C.T. (1947) O carpôgonio de Chiodecton sphaerale Ach. Boletim da Sociedade Brasileira de Agronomia, 10, 63-65.

Rizzini, C.T. (1952) Lichenes in Horto Botanico Fluminis Januarii crescentes. I. Arquivos do Jardim Botânico do Rio de Janeiro, 12, 189-202.
Roberts, L. (1992) Chemical prospecting: hope for vanishing ecosystems? Science, 256 (5060), 1142-1144. https://doi.org/10.1126/science.256.5060.1142

Rodman, J.E. \& Cody, J.H. (2003) The taxonomic impediment overcome: NSF's partnerships for enhancing expertise in taxonomy (PEET) as a model. Systematic Biology, 52 (3), 428-435.

https://doi.org/10.1080/10635150390197055

Rokas, A., Payne, G., Fedorova, N.D., Baker, S.E., Machida, M., Yu, J., Georgianna, D.R., Dean, R.A., Bhatnagar, D., Cleveland, T. E. \& Wortman, J. R. (2007) What can comparative genomics tell us about species concepts in the genus Aspergillus? Studies in Mycology, 59, 11-17. https://doi.org/10.3114/sim.2007.59.02

Roskov, Y., Ower, G., Orrell, T., Nicolson, D., Bailly, N., Kirk, P.M., Bourgoin, T., DeWalt, R.E., Decock, W., Nieukerken, E. v., Zarucchi, J. \& Penev, L. (Eds.) 2019. Species 2000 \& ITIS Catalogue of Life, 2019 Annual Checklist. Available from: http://www.catalogueoflife.org/annual-checklist/ 2019. Species 2000, Naturalis, Leiden, Netherlands.

Rossman, A. (1994) A strategy for an all-taxa inventory of fungal biodiversity. In: Peng, C. I. \& Chou, C. H. (Eds.), Biodiversity and Terrestrial Ecosystems (Academia Sinica Monograph Series No. 14). Taipei, pp. 169-194.

Rubin, S.M. \& Fish, S.C. (1994) Biodiversity prospecting: using innovative contractual provisions to foster ethnobotanical knowledge, technology, and conservation. Colorado Journal of International Environmental Law and Policy, 5, 23-58.

Samuels, G.J. \& Seifert, K.A. (1995) The impact of molecular characters on systematics of filamentous ascomycetes. Annual Review of Phytopathology, 33 (1), 37-67. https://doi.org/10.1146/annurev.py.33.090195.000345

Sayers, E.W., Cavanaugh, M., Clark, K., Ostell, J., Pruitt, K.D. \& Karsch-Mizrachi, I. (2019) GenBank. Nucleic Acids Research, 47 (D1), D94-D99. https://doi.org/10.1093/nar/gky989

Schmit, J.P. \& Mueller, G.M. (2007) An estimate of the lower limit of global fungal diversity. Biodiversity and Conservation, 16 (1), 99-111. https://doi.org/10.1007/s10531-006-9129-3

Schultz, P.W. (2002) Inclusion with nature: The psychology of human-nature relations. In: In: Schmuck P. \& Schultz W.P. (Eds.), Psychology of Sustainable Development. Springer, Boston, pp. 61-78. https://doi.org/10.1007/978-1-4615-0995-0_4

Schumm F. \& Aptroot, A. (2010) Seychelles Lichen Guide. Beck, Süssen, 404 pp.

Schumm, F. \& Aptroot, A. (2012a) A Microscopical Atlas of Some Tropical Lichens from SE-Asia: Thailand, Cambodia, Philippines, Vietnam. Volume 1. Books on Demand, Norderstedt, $460 \mathrm{pp}$.

Schumm, F. \& Aptroot, A. (2012b) A Microscopical Atlas of Some Tropical Lichens from SE-Asia: Thailand, Cambodia, Philippines, Vietnam. Volume 2. Books on Demand, Norderstedt, $432 \mathrm{pp}$.

Schumm, F. \& Aptroot, A. (2019a) Images of the Lichen Genus Caloplaca, Vol. 1. Books on Demand, Norderstedt, 688 pp.

Schumm, F. \& Aptroot, A. (2019b) Images of the Lichen Genus Caloplaca, Vol. 2. Books on Demand, Norderstedt, 688 pp.

Schumm, F. \& Aptroot, A. (2019c) Images of the Lichen Genus Caloplaca, Vol. 3. Books on Demand, Norderstedt, 693 pp.

Schumm, F. \& Aptroot, A. (2019d) Images of the Lichen Genus Caloplaca, Vol. 4. Books on Demand, Norderstedt, 688 pp. 
Schumm, F. \& Elix, J.A. (2015) Atlas of Images of Thin Layer Chromatograms of Lichen Substances-Bilderatlas von Dünnschichtchromatogrammen von Flechten-Inhaltsstoffen. Books on Demand, Norderstedt, 584 pp.

Sharma, O.P. (1993) Plant Taxonomy. McGraw-Hill, New Dehli, 482 pp.

Shear, C.L. \& Dodge, B. O. (1927) Life histories and heterothallism of the red bread-mold fungi of the Monilia sitophila group. Journal of Agricultural Research, 34 (11), 1019-1042.

Shewan, L. G. \& Coats, A. J. (2010) Ethics in the authorship and publishing of scientific articles. International Journal of Cardiology, 144 (1), 1-2. https://doi.org/10.1016/j.ijcard.2010.07.030

Shrimpton, R. (2019) GIFT, transnational corporations and the sixth mass extinction. World Nutrition, 10 (4), 143-146. https://doi.org/10.26596/wn.2019104143-146

$\mathrm{Si}$, A. (2016) Ethnotaxonomies and universals: investigating some key assumptions. In: Si, A. (Ed.), The Traditional Ecological Knowledge of the Solega. Springer, Cham, pp. 31-55. https://doi.org/10.1007/978-3-319-24681-9_2

Simijaca, D., Moncada, B. \& Lücking, R. (2018) Bosque de roble o plantación de coníferas, ¿qué prefieren los líquenes epífitos? Colombia Forestal, 21, 123-141. https://doi.org/10.14483/2256201X.12575

Sipman, H.J.M. \& Aguirre-C., J. (1982) Contribucion al conocimiento de los liquenes de Colombia-1. Clave generica para los liquenes foliosos y fruticosos de los paramos colombianos. Cladasia, 12, 603-634.

Sipman, H.J.M., Lücking, R., Aptroot, A., Chaves, J.L., Kalb, K. \& Umaña, L. (2012) A first assessment of the TICOLICHEN biodiversity inventory in Costa Rica and adjacent areas: the thelotremoid Graphidaceae (Ascomycota: Ostropales). Phytotaxa, 55 (1), 1-214.

httpS://doi.org/10.11646/phytotaxa.55.1.1

SIPRI (2019) World military expenditure grows to $\$ 1.8$ trillion in 2018. Available from: https://www.sipri.org/media/pressrelease/2019/world-military-expenditure-grows-18-trillion2018 (accessed 28 January 2020).

Sittenfeld, A., Tamayo, G., Nielsen, V., Jiménez, A., Hurtado, P., Chinchilla, M., Guerrero, O., Mora, M.A., Rojas, M., Blanco, R. \& Alvarado, E. (1999) Costa Rican international cooperative biodiversity group: using insects and other arthropods in biodiversity prospecting. Pharmaceutical Biology, 37 (1), 55-68.

https://doi.org/10.1076/1388-0209(200010)37:SUP;1$\mathrm{W} ; \mathrm{FT} 055$

Sluys, R. (2013) The unappreciated, fundamentally analytical nature of taxonomy and the implications for the inventory of biodiversity. Biodiversity and Conservation, 22, 1095-1105. https://doi.org/10.1007/s10531-013-0472-x

Smith, D., da Silva, M., Jackson, J. \& Lyal, C. (2017) Explanation of the Nagoya Protocol on Access and Benefit Sharing and its implication for microbiology. Microbiology, 163 (3), 289-296. https://doi.org/10.1099/mic.0.000425

Smith, G.F. \& Figueiredo, E. (2011) Responsible species description: A change of attitude is needed to facilitate and improve access to biological material. Taxon, 60 (6), 1549-1551. https://doi.org/10.1002/tax.606001

Snader, M. \& McCloud, T.G., 1994. Ethnobotany and drug discovery: the experience of the US National Cancer Institute. In: Prance, G.T., Chadwick, D. \& Marsh, J. (Eds.), Ethnobotany and the Search for New Drugs (Ciba Foundation Symposium 185). Wiley, Chichester, pp. 178-196.
Sneath, P.H. \& Sokal, R.R. (1973) Numerical taxonomy. The principles and Practice of Numerical Classification. Freeman \& Co., San Francisco, 573 pp.

Soejarto, D.D., Gyllenhaal, C., Fong, H.H.S., Xuan, L.T., Hiep, N.T., Hung, N.V., Bich, T.Q., Southavong, B., Sydara, K. \& Pezzuto, J.M. (2004) The UIC ICBG (University of Illinois at Chicago International Cooperative Biodiversity Group) Memorandum of Agreement: A model of benefitsharing arrangement in natural products drug discovery and development. Journal of Natural Products, 67 (2), 294-299. https://doi.org/10.1021/np0304363

Soga, M., Gaston, K. J., Koyanagi, T.F., Kurisu, K. \& Hanaki, K. (2016) Urban residents' perceptions of neighbourhood nature: Does the extinction of experience matter? Biological Conservation, 203, 143-150. https://doi.org/10.1016/j.biocon.2016.09.020

Sokal, R.R. \& Sneath, P.H. (1963) The principles and practice of numerical taxonomy. Taxon, 12 (5), 190-199.

South, N. (2017) The corporate 'colonization of nature': bio-piracy and the development of green criminology. In: White, E. (ed.), Transnational Environmental Crime. Routledge, London, New York, pp. 341-358. https://doi.org/10.4324/9781315084589

Spector, J.M., Harrison, R.S. \& Fishman, M.C. (2018) Fundamental science behind today's important medicines. Science Translational Medicine, 10 (438), eaaq1787. https://doi.org/10.1126/scitranslmed.aaq1787

Stevens, P.F. (2001) History of Taxonomy. eLS (Encyclopedia of Life Sciences)

https://doi.org/10.1038/npg.els.0003093

Stevenson, R.D., Haber, W.A. \& Morris, R.A. (2003) Electronic field guides and user communities in the eco-informatics revolution. Conservation Ecology 7(1), 3 [online] http://www.consecol.org/vol7/iss 1/art3

Stork, N.E. (2018) How many species of insects and other terrestrial arthropods are there on Earth? Annual Review of Entomology, $63,31-45$. https://doi.org/10.1146/annurev-ento-020117-043348

Subramanian, C.V. (1982) Tropical mycology: future needs and development. Current Science, 51 (7), 321-325.

Suffness, M., Cragg, G.G., Grever, M.M., Grifo, F.F., Johnson, G., Mead, J.A.R., Schepartz, S.S., Venditti, J.J. \& Wolpert, M. (1995) The National Cooperative Natural Products Drug Discovery Group (NCNPDDG) and International Cooperative Biodiversity Group (ICBG) Programs. International journal of Pharmacognosy, 33 (Supplement 1), 5-16. https://doi.org/10.3109/13880209509067083

Tahseen, Q. (2014) Taxonomy-the crucial yet misunderstood and disregarded tool for studying biodiversity. Journal of Biodiversity \& Endangered Species, 2, 128. https://doi.org/10.4172/2332-2543.1000128

Taylor, J.W., Jacobson, D.J., Kroken, S., Kasuga, T., Geiser, D.M., Hibbett, D.S. \& Fisher, M.C. (2000) Phylogenetic species recognition and species concepts in fungi. Fungal Genetics and Biology, 31 (1), 21-32. https://doi.org/10.1006/fgbi.2000.1228

Texeira da Silva, J.A. \& Dobránszki, J. (2016) Multiple authorship in scientific manuscripts: ethical challenges, ghost and guest/ gift authorship, and the cultural/disciplinary perspective. Science and Engineering Ethics, 22 (5), 1457-1472. https://doi.org/10.1007/s11948-015-9716-3

Thell, A., Crespo, A., Divakar, P.K., Kärnefelt, I., Leavitt, S.D., Lumbsch, H.T. \& Seaward, M.R. (2012) A review of the 
lichen family Parmeliaceae-history, phylogeny and current taxonomy. Nordic Journal of Botany, 30 (6), 641-664. https://doi.org/10.1111/j.1756-1051.2012.00008.x

Torres-Salinas, D., Robinson-Garcia, N., Campanario, J.M. \& López-Cózar, E.D. (2014) Coverage, field specialisation and the impact of scientific publishers indexed in the Book Citation Index. Online Information Review, 38 (1), 24-42. https://doi.org/10.1108/OIR-10-2012-0169

Turland, N.J., Wiersema, J.H., Barrie, F.R., Greuter, W., Hawksworth, D.L., Herendeen, P.S., Knapp, S., Kusber, W.H., Li, D.Z., Marhold, K. \& May, T.W. (2018) International Code of Nomenclature for Algae, Fungi, and Plants (Shenzhen Code) adopted by the Nineteenth International Botanical Congress Shenzhen, China, July 2017. [Regnum Vegetabile Vol. 159.]. Koeltz Botanical Books, Glashütten, xxxviii +254 pp. https://doi.org/10.12705/Code.2018

Turner, R.K., Paavola, J., Cooper, P., Farber, S., Jessamy, V. \& Georgiou, S. (2003) Valuing nature: lessons learned and future research directions. Ecological Economics, 46 (3), 493-510. https://doi.org/10.1016/S0921-8009(03)00189-7

Turner, W.R., Brandon, K., Brooks, T. M., Gascon, C., Gibbs, H.K., Lawrence, K.S., Mittermeier, R.A. \& Selig, E.R. (2012) Global biodiversity conservation and the alleviation of poverty. Bioscience, 62 (1), 85-92. https://doi.org/10.1525/bio.2012.62.1.13

Umaña, L. \& Sipman, H. J. M. (2002) Líquenes de Costa RicaCosta Rica Lichens. INBio, Santo Domingo, $156 \mathrm{pp}$.

UNESCO (2015) UNESCO Science Report: Towards 2030. UNESCO Publishing, Paris, 820 pp.

Van der Velde, G. (2001) Taxonomists make a name for themselves. Nature, 414, 148. https://doi.org/10.1038/35102739

Vinarski, M.V. (2019) The roots of the taxonomic impediment: Is the 'integrativeness'a remedy? Integrative Zoology, 15 (1), $2-15$. https://doi.org/10.1111/1749-4877.12393

Vink, C.J., Paquin, P. \& Cruickshank, R.H. (2012) Taxonomy and irreproducible biological science. BioScience, 62 (5), 451452 . https://doi.org/10.1525/bio.2012.62.5.3

Wägele, H., Klussmann-Kolb, A., Kuhlmann, M., Haszprunar, G., Lindberg, D., Koch, A. \& Wägele, J.W. (2011) The taxonomist-an endangered race. A practical proposal for its survival. Frontiers of Zoology, 8, 25. https://doi.org/10.1186/1742-9994-8-25

Wake, D.B. \& Vredenburg, V.T. (2008) Are we in the midst of the sixth mass extinction? A view from the world of amphibians. Proceedings of the National Academy of Sciences, 105 (Supplement 1), 11466-11473.

https://doi.org/10.1073/pnas.0801921105

Watanabe, M.E. (2015) The Nagoya Protocol on Access and Benefit Sharing: International treaty poses challenges for biological collections. Bioscience, 65 (6), 543-550.

https://doi.org/10.1093/biosci/biv056

Watson, M. F., Lyal, C. H. \& Pendry, C. A. (Eds.) (2015) Descriptive Taxonomy: The Foundation of Biodiversity Research (Systematics Association Special Volume 84). Cambridge University Press, Cambridge, 349 pp.

Weerakoon, G., Aptroot, A., Lumbsch, H.T., Wolseley, P.A. Wijeyaratne, S.C. \& Gueidan, C. (2012) New molecular data on Pyrenulaceae from Sri Lanka reveal two well-supported groups within this family. The Lichenologist, 44 (5), 639-664. https://doi.org/10.1017/S0024282912000333
Weerakoon, G., Wolseley, P.A., Arachchige, O., Cáceres, M.E.S., Jayalal, U. \& Aptroot, A. (2016) Eight new lichen species and 88 new records from Sri Lanka. The Bryologist, 119 (2), $131-142$. https://doi.org/10.1639/0007-2745-119.2.131

Weiss, C. \& Eisner, T. (1998) Partnerships for value-added through bioprospecting. Technology in Society, 20 (4), 481-498. https://doi.org/10.1016/S0160-791X(98)00029-3

Werner, Y.L. (2006) The case of impact factor versus taxonomy: a proposal. Journal of Natural History, 40, 1285-1286. https://doi.org/10.1080/00222930600903660

Werner, Y.L. (2009) The aspiration to be good is bad: The "Impact Factor" hurts both science and society. International Journal of Science in Society, 1, 99-105. https://doi.org/10.18848/1836-6236/CGP/v01i01/51264

Westman, W.E. (1977) How much are nature's services worth? Science, 197 (4307), 960-964. https://doi.org/10.1126/science.197.4307.960

Wheeler, Q.D. (2004) Taxonomic triage and the poverty of phylogeny. Philosophical Transactions of the Royal Society of London. Series B: Biological Sciences, 359 (1444), 571-583. https://doi.org/10.1098/rstb.2003.1452

Wheeler, Q.D. (2008) Taxonomic shock and awe. In: Wheeler, Q. D. (Ed.), The New Taxonomy. CRC Press, Boca Raton, pp. 211-226.

Wheeler, Q.D. (2010) What would NASA do? Mission-critical infrastructure for species exploration. Systematics and Biodiversity, 8, 11-15. https://doi.org/10.1080/14772001003628075

Wheeler, Q.D. (2018) Blank canvas: The case for descriptive taxonomy. Integrative and Comparative Biology, 58, 11181121 . https://doi.org/10.1093/icb/icy067

White, L. (1967) The historical roots of our ecologic crisis. Science, 155 (3767), 1203-1207. https://doi.org/10.1126/science.155.3767.1203

Widhelm, T.J., Grewe, F., Huang, J.P., Mercado-Díaz, J.A., Goffinet, B., Lücking, R., Moncada, B., Mason-Gamer, R. \& Lumbsch, H.T. (2019) Multiple historical processes obscure phylogenetic relationships in a taxonomically difficult group (Lobariaceae, Ascomycota). Scientific Reports, 9 (1), 1-16. https://doi.org/10.1038/s41598-019-45455-x

Wildman, H.G. (2003) The fall and rise of natural products screening for drug discovery. Fungal Diversity, 13, 231-241.

Wikipedia (2020) List of countries by research and development spending. Available from: https://en.wikipedia.org/wiki/ List_of_countries_by_research_and_development_spending (accessed 28 January 2020)

Wilkins, J.S. (2011) What is systematics and what is taxonomy? Evolving Thoughts. Available from: https://evolvingthoughts. net/2011/02/05/what-is-systematics-and-what-is-taxonomy (accessed 28 January 2020)

Wilson, E.O. (1976) What is nature worth? The Wilson Quarterly, 26 (1), 20-39.

Wilson, E.O. (2005) The Linnaean enterprise: Past, present, and future. Proceedings of the American Philosophical Society, 149 (3), 344-348.

Winston, J.E. (1999) Describing Species: Practical Taxonomic Procedure for Biologists. Columbia University Press, New York, $512 \mathrm{pp}$.

Wu, B., Hussain, M., Zhang, W., Stadler, M., Liu, X. \& Xiang, M. (2019) Current insights into fungal species diversity and perspective on naming the environmental DNA sequences of fungi. Mycology, 10, 127-140. https://doi.org/10.1080/21501203.2019.1614106 
Wyatt, T. (2014) Invisible pillaging: The hidden harm of corporate biopiracy. In: Davies, P., Francis, P. \& Wyatt, T. (Eds.), Invisible Crimes and Social Harms. Palgrave Macmillan, London, pp. 161-177.

Xavier-Filho, L. \& Kurokawa, S. (1971) A note on basidiolichens found in Pernambuco, Brazil. Universidade Federal de Pernambuco, Centro de Biociencias, Departamento de Botânica, Serie B, 2 (1), 1-6.

Young, T.R. (2013) An international cooperation perspective on the implementation of the Nagoya Protocol. In: Morgera, E., Buck, M. \& Tsioumani, E. (Eds.), The 2010 Nagoya Protocol on Access and Benefit-sharing in Perspective, Brill Nijhoff, pp. 451-505.

https://doi.org/10.1163/9789004217201_017

Zakrzewski, P.A. (2002) Bioprospecting or biopiracy? The pharmaceutical industry's use of indigenous medicinal plants as a source of potential drug candidates. University of Toronto Medical Journal, 79 (3), 252-254.

Zebich-Knos, M. (1997) Preserving biodiversity in Costa Rica: The case of the Merck-INBio agreement. The Journal of Environment \& Development, 6 (2), 180-186. https://doi.org/10.1177/107049659700600206 